\title{
ANTI-HER2 ANTIBODIES IN COMBINATION WITH CHEMOTHERAPY OR CHEMOTHERAPY-FREE REGIMENS TARGETING HER2-POSITIVE BREAST CANCER: A SYSTEMATIC REVIEW
}

\author{
Siti Muhamad Nur Husna1, Faezahtul Arbaeyah Hussain², Maya Mazuwin Yahya ${ }^{3}$, Anne Dyhl-Polk ${ }^{4}$, and \\ Kah Keng Wong ${ }^{1}$
}

\author{
${ }^{1}$ Department of Immunology, School of Medical Sciences, Universiti Sains Malaysia, 16150 Kubang Kerian, Kelantan, \\ Malaysia \\ ${ }^{2}$ Department of Pathology, School of Medical Sciences, Universiti Sains Malaysia,16150 Kubang Kerian, Kelantan, \\ Malaysia \\ ${ }^{3}$ Department of Surgery, School of Medical Sciences, Universiti Sains Malaysia,16150 Kubang Kerian, Kelantan, \\ Malaysia \\ ${ }^{4}$ Department of Oncology, Herlev-Gentofte University Hospital, Herlev Ringvej 75, 2730 Herlev, Denmark
}

Corresponding author: Assoc. Prof. Dr. Kah Keng Wong

Email: kahkeng@usm.my

\begin{abstract}
Breast cancer is the leading cause of cancer-related death in female worldwide. Human epidermal growth factor receptor 2 (HER2) amplification is observed in approximately $20 \%$ of breast cancer cases and is associated with poor clinical outcomes. Dual HER2 blockade without chemotherapy represents an attractive therapeutic approach, and it remains unresolved if anti-HER2 therapeutic antibodies are sufficient to replace chemotherapy regimens. In this review, we discuss the approved therapeutic monoclonal antibodies (pertuzumab and trastuzumab) and antibody-drug conjugate (trastuzumab emtansine or T-DM1) for the treatment of HER2-positive breast cancer patients. In summary, phase II and III clinical trials have demonstrated that dual HER2 blockade (pertuzumab and trastuzumab) plus chemotherapy regimens confer better efficacy compared with dual HER2 blockade alone, or anti-HER2 antibody monotherapy, in HER2-positive breast cancer patients. Dual HER2 blockade (pertuzumab and trastuzumab) combined with chemotherapies (5-fluorouracil, epirubicin, cyclophosphamide and docetaxel) yield superior response. Moreover, dual HER2 blockade (T-DM1 and pertuzumab) in combination with docetaxel represents a promising treatment regimen containing T-DM1. Ongoing clinical trials are assessing the optimal chemotherapy of choice with anti-HER2 antibodies combinations. In conclusion, improved outcomes are attributable to selection for the optimal chemotherapy regimen in combination with anti-HER2 antibodies instead of replacing chemotherapy altogether with the current line of antiHER2 therapeutic antibodies.
\end{abstract}

Keywords: Breast cancer; HER2-positive; trastuzumab; pertuzumab; T-DM1

\section{INTRODUCTION}

Breast cancer is the most prevalent cancer and the leading cause of cancer-related death in female worldwide ${ }^{1,2}$, and it accounts for approximately $30 \%$ of all new cancer cases ${ }^{3}$. Immunohistochemistry (IHC) detection of receptors is used to diagnose breast cancer including estrogen receptor (ER), progesterone receptor (PR), and human epidermal growth factor receptor 2 (HER2) ${ }^{4,5}$. In situ hybridization for HER2 gene amplification is conducted either upfront or in IHC borderline cases ${ }^{6}$.

HER2 plays vital roles in cell growth and survival, and it is expressed at low levels in epithelial cells of certain normal human tissues ${ }^{7,8}$. Amplification of HER2 is observed in about $20 \%$ of breast cancer cases associated with worse outcomes ${ }^{9,10}$, hence anti-HER2 therapeutic antibodies represent a rational therapeutic strategy for HER2overexpressing breast cancer. The structure, functions and therapeutic antibodies targeting HER2 is presented in Figure 1.
The Food and Drug Administration (FDA)-approved therapeutic monoclonal antibodies (mAbs; trastuzumab and pertuzumab) and antibody-drug conjugate (ADC; trastuzumab emtansine or TDM1) have enhanced the clinical response and outcomes of HER2-positive breast cancer patients. Dual HER2 blockade without chemotherapy represents an attractive therapeutic approach, and questions remain if anti-HER2 therapeutic antibodies are sufficient to replace chemotherapy regimens.

In this review, we present and discuss the mAbs (trastuzumab and pertuzumab) and ADC (T-DM1) targeting HER2-positive breast cancer to address the aforementioned issue. The series of phase II and III clinical trials either as single agents (monotherapy) or in combination with chemotherapy or chemotherapy-free regimens were shortlisted, described and discussed. 


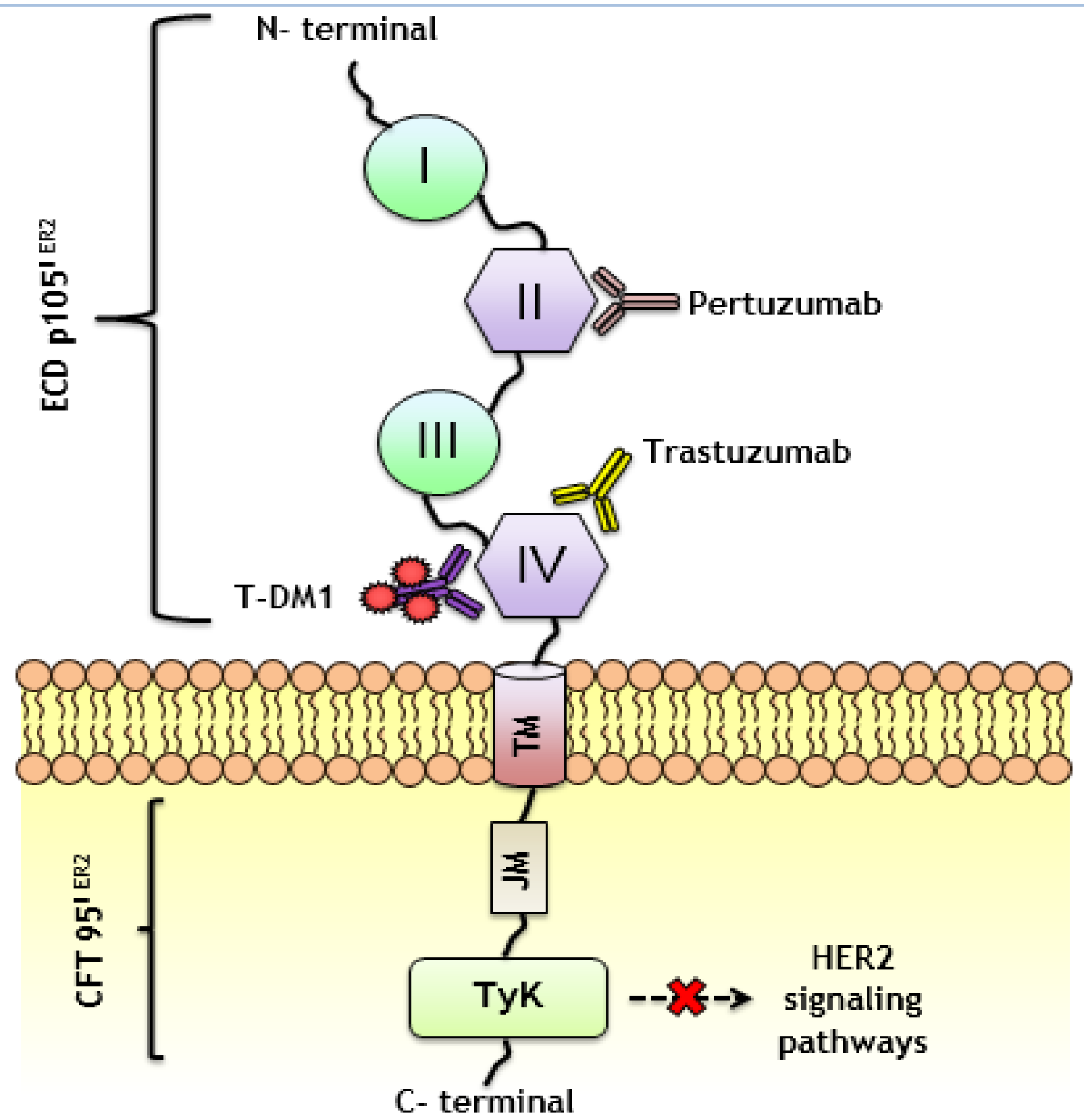

Figure 1: The structure and domains of HER2, and therapeutic antibodies targeting HER2.

HER2 is a type 1 transmembrane glycoprotein composed of three distinct regions i.e. N-terminal extracellular domain (ECD), a single a-helix transmembrane domain (TM), and an intracellular tyrosine kinase (TyK) domain. $\mathrm{N}$-terminal ECD is divided into four subdomains (I-IV). Domains I and III are leucine-rich domains responsible for ligand binding while domains II and IV are cysteine-rich domains responsible for receptor dimerization. TM domain of HER2 is critically involved in HER2 signaling by stabilizing dimerization and also by controlling structural reorganizations. Intracellular domain is composed of a cytoplasmic juxtamembrane (JM) linker, a tyrosine kinase (TyK) domain and a carboxyl-terminal tail (CFT). TyK domain autophosphorylation leads to the activation of tyrosine kinase downstream signaling pathways such as PI3K and MAPK pathways. Trastuzumab and T-DM1 target domain IV while pertuzumab targets domain II of HER2 to block its activation and downstream signaling pathways. 


\section{METHODS}

For clinical trial studies, the electronic databases Google Scholar, PubMed, and ClinicalTrials.gov (http://www.clinicaltrials.gov) were used to search relevant literature using the following search terms: (breast cancer OR HER2 breast cancer OR metastatic breast cancer) AND (trastuzumab OR pertuzumab OR trastuzumab emtansine OR T-DM1) AND (monotherapy OR combination $\mathrm{OR}$ combination regimen). All articles were selected and reviewed in accordance with Preferred Reporting Items for Systematic Reviews and Meta-Analyses (PRISMA) guidelines. All studies were searched and screened by two investigators (S.M.N.H., K.K.W.) independently, and disagreements were resolved through discussions by both investigators for a consensus. Only English language studies and clinical trials were included, and the literature was searched from inception to $22^{\text {nd }}$ April 2019. Abstracts and proceedings were included while case reports, reviews, letters, editorials, observational, retrospective, pre-clinical or in vitro studies, other non-clinical trial studies, and studies without endpoint analysis were excluded. To identify additional relevant studies, the bibliographic references of all retrieved articles were manually searched, and the 'Cited by' function available on Google Scholar was utilized. A total of 55 studies met the inclusion criteria and they were included in this review (Figure 2).

Data was collected from the final shortlisted studies to gather the following information: types of anti-HER2 antibodies (i.e. trastuzumab, pertuzumab or T-DM1), phase, patient population (i.e. HER-2 positive early, metastatic breast cancer $[\mathrm{MBC}]$ or advanced disease), combination with chemotherapy or chemotherapy-free regimens, pre-treatment (i.e. with or without), endpoints (i.e. objective response rate [ORR], complete response [CR], partial response [PR], stable disease [SD], clinical benefit rate [CBR], progression-free survival [PFS], disease-free survival [DFS], overall survival [OS], pathological complete response [pCR]). The data was extracted by S.M.N.H. and K.K.W. independently, and each investigator cross-checked the data to confirm accuracy. All data was presented and compared as extracted without additional downstream statistical analysis.

\section{RESULTS AND DISCUSSION}

\section{Trastuzumab}

Trastuzumab (Herceptin) is the first FDAapproved recombinant $\mathrm{mAb}$ for the treatment of HER2-positive MBC. Trastuzumab is composed of two antigen-specific sites that bind to the juxtamembrane portion of the HER2 receptor extracellular domain (ECD) which blocks the activation of its intracellular tyrosine kinase domain ${ }^{11,12}$. Trastuzumab binds to the domain IV of HER2 receptor which disrupts HER2 homodimerization and prevents the cleavage of $\mathrm{ECD}$, thereby preventing the formation of $\mathrm{P} 95^{\text {HER2 }}$, the active truncated receptor ${ }^{13,14}$.

\section{Trastuzumab monotherapy}

A phase I trial of trastuzumab treatment in HER2overexpressing $M B C$ patients revealed that the tolerable dose of trastuzumab was $10-500 \mathrm{mg}$ in single dose or once weekly ${ }^{15}$. A subsequent phase II trial assessed the efficacy of single agent trastuzumab in HER2-positive breast cancer patients $(n=43)^{16}$. The ORR was $11 \%$ including one achieving CR (2.3\%). In a large, multinational phase II trial of trastuzumab treatment performed in women with HER2-positive MBC $(n=222), 15 \%$ $(n=33)$ achieved ORR, 3.6\% $(n=8)$ achieved CR and 11.7\% $(n=26)$ showed $P^{17}$.

Another phase II trial of trastuzumab monotherapy in HER2-overexpressing MBC patients $(n=114)$ demonstrated ORR of $26 \%$, with 6.1\% achieved CR $(n=7)$ and $20.2 \%$ achieved PR $(n=23)^{18}$. Moreover, in a phase II trial assessing the efficacy of trastuzumab monotherapy (first-line treatment) in HER2-positive MBC $(n=105)^{19}$. The ORR reported in the intent-to-treat population was $19 \%(1.9 \% C R, n=2 ; 17.1 \% P R, n=18)$, CBR was $33 \%$ and median time to progression was 3.4 months. The trastuzumab monotherapy given on a 3-weekly schedule was well tolerated.

The phase III randomized trial HERA (BIG 1-01) was an international, multicentre, open-label trial that enrolled patients with HER2-positive early breast cancer $(n=5,102)$ after adjuvant chemotherapy, and 5,099 patients of the intentto-treat population underwent follow-up for 11 years ${ }^{20}$. The patients were randomly assigned $(1: 1: 1)$ to receive trastuzumab for one year $(n=1,702)$ or for two years $(n=1,700)$, or to be in the observation group (without trastuzumab; $\mathrm{n}=1,697)$. One year of trastuzumab reduced the risk of a DFS event ( $\mathrm{HR}=0.76$; $95 \% \mathrm{Cl}$ : $0.68-0.86)$ and death $(\mathrm{HR}=0.74 ; 95 \% \mathrm{Cl}: 0.64-0.86)$, and improved DFS compared with the observation group (ten-year DFS $69 \%$ vs $63 \%$, respectively). Two years of adjuvant trastuzumab did not improve DFS outcomes (HR=1.02; $95 \% \mathrm{Cl}$ : 0.89 1.17; ten-year DFS: $69 \%$ ) compared with one year of trastuzumab ${ }^{20}$. Hence, the long-term, 11-year follow-up demonstrated the lack of clinical benefits to prolong trastuzumab monotherapy treatment over a year that would expose patients to side effects.

\section{Trastuzumab in combination with chemotherapy}

A phase II trial assessed the safety profile of trastuzumab plus paclitaxel (administered for 12 weeks) followed by nine months of trastuzumab monotherapy in HER2-positive breast cancer patients $(n=406)$. The primary endpoint of this study was 3-year invasive DFS (iDFS) reported to be $98.7 \%(n=401 ; 95 \% \mathrm{Cl}: 97.6-99.8 \%)^{21}$. 


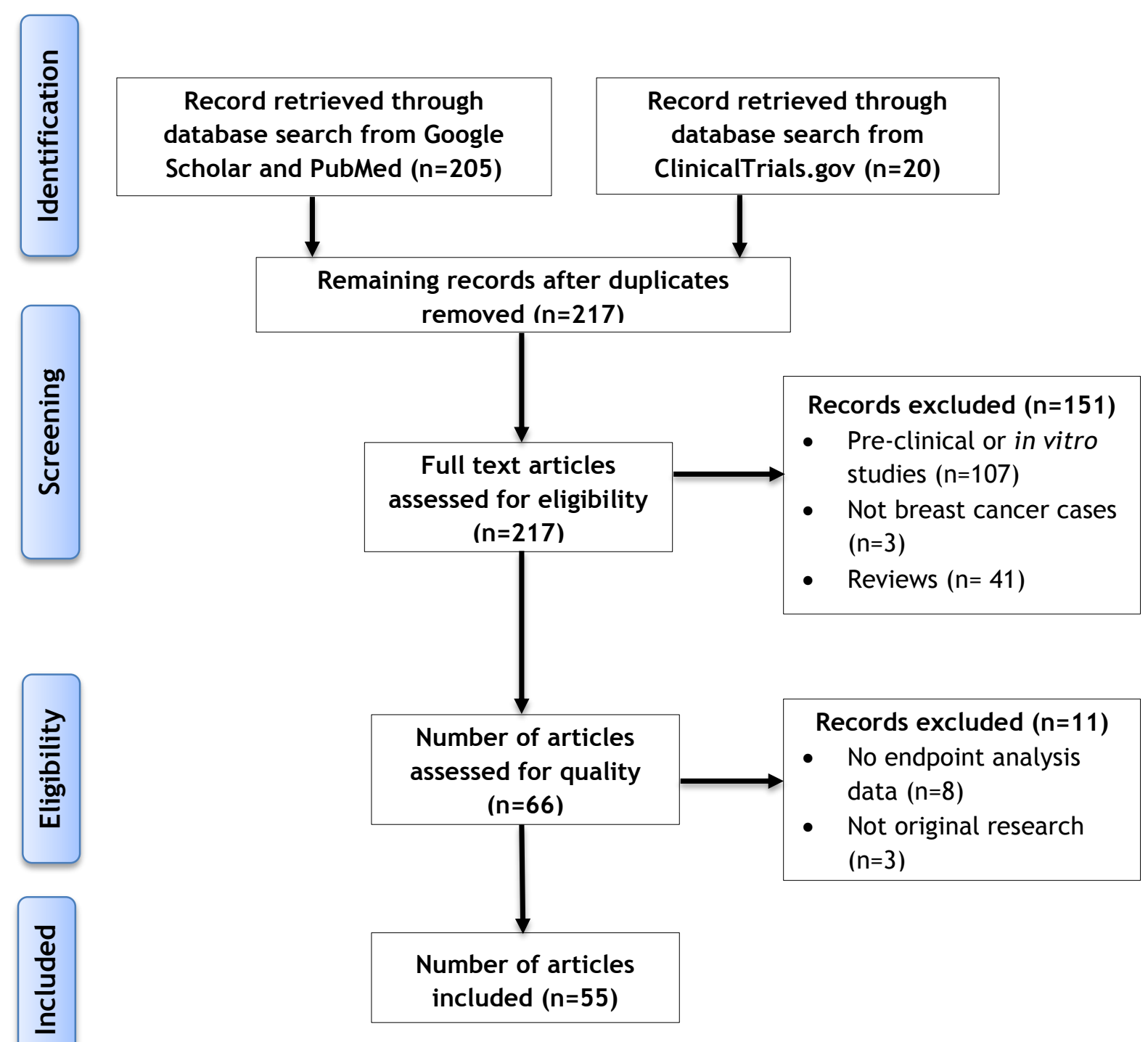

Figure 2: PRISMA flow diagram summarizing the study selection process.

A total of 55 articles were included in the review.

The phase II trial (NEfERT-T) was conducted in the first-line treatment of recurrent and/or HER2positive $M B C$ patients previously exposed to trastuzumab or lapatinib. This trial aimed to compare the efficacy of neratinib plus paclitaxel $(\mathrm{n}=242)$ and trastuzumab plus paclitaxel $(\mathrm{n}=237)^{22}$. The median PFS for both groups was 12.9 months $(\mathrm{HR}=1.02 ; 95 \% \mathrm{Cl}, 0.81-1.27 ; p=0.89)$, indicating that their clinical benefits in terms of PFS was comparable.

In a randomized phase III trial, the efficacy of trastuzumab and paclitaxel with or without carboplatin as first-line therapy was studied in HER2-overexpressing MBC patients $(n=196)$. The ORR for trastuzumab-paclitaxel-carboplatin (TPC) was $52 \% \quad(n=102)$ versus $36 \% \quad(n=71)$ for trastuzumab-paclitaxel (TP). Meanwhile, the PFS was 10.7 months and 7.1 months for TPC and TP, respectively ${ }^{23}$.

CALGB 40601 three-arm randomized phase III trial compared the combination of paclitaxel plus trastuzumab $(\mathrm{TH}, \mathrm{n}=120)$ with or without the addition of lapatinib (THL, $n=118$ ) to the control arm of paclitaxel plus lapatinib ( $T L, n=67)$ in stage II to III HER2-positive breast cancer patients 16 weeks before surgery ${ }^{24}$. The pCR rate of THL, TH and TL was $56 \%, 46 \%$ and $32 \%$, respectively. PCR of dual HER2-targeted therapy was not significantly higher than single HER2 targeting.

Another phase III trial (LUX-Breast 1) compared afatinib plus vinorelbine $(n=339)$ with trastuzumab plus vinorelbine $(n=169)$ in patients with HER2-overexpressing MBC who had progressed on prior adjuvant trastuzumab ${ }^{25}$. The trastuzumab group exhibited enhanced median OS of 28.6 months compared with 19.6 months in afatinib group, however their median PFS and ORR were comparable (median PFS of 5.6 months vs 5.5 months; ORR of $47 \%$ vs $46 \%$ ). 


\section{Trastuzumab in combination with} chemotherapy free regimens

In recent years, growing number of clinical trials have combined trastuzumab with specific inhibitors. In a phase 1b trial, HER2-positive progressive breast cancer with prior trastuzumab, pertuzumab, and trastuzumab emtansine $(n=60)$ were treated with tucatinib (HER2 tyrosine kinase inhibitor) in combination with capecitabine or trastuzumab ${ }^{26}$. In patients with measurable disease, the achieved ORR for tucatinibcapecitabine combination was $83 \% \quad(n=5$ of 6 patients), but lower in tucatinib-trastuzumab combination with $40 \%$ ( $n=6$ of 15 patients). However, the combinations had acceptable toxicity with preliminary anti-tumor activity. In a phase II study of trastuzumab-resistant HER2positive advanced breast cancer, the patients $(\mathrm{n}=50)$ received both buparlisib (pan-class I PI3K inhibitor) and trastuzumab ${ }^{27}$. The safety profile was acceptable but the primary endpoint of ORR $\geq 25 \%$ was not achieved as the resulting ORR was only $10 \%$, suggesting the requirement of chemotherapy to achieve better clinical outcomes.

Another phase III trial (NeoALLTO) was conducted on HER2-positive primary breast cancer patients receiving single agent lapatinib $(n=154)$, trastuzumab monotherapy $(n=149)$ or trastuzumab-lapatinib combination $(n=152)^{28}$. The PCR rate was higher in the combination group since $51.3 \%$ of the $(n=78)$ patients achieved $p C R$ compared with $29.5 \%$ in the group given trastuzumab alone $(\mathrm{n}=44)$. No significant difference was observed in $\mathrm{PCR}$ between the lapatinib and trastuzumab groups.

In a recent (2018) phase III trial, dual HER2 blockade was conducted with lapatinib plus trastuzumab (TRAS) combined with an aromatase inhibitor (Al) in postmenopausal women with HER2-positive/HR-positive MBC with prior endocrine treatment and prior neo(adjuvant)/first-line TRAS plus chemotherapy ${ }^{29}$. Patients were randomly assigned to receive lapatinib+TRAS+AI $(n=120)$, TRAS+Al $(n=117)$, or lapatinib+Al $(n=118)$. Superior PFS was observed in lapatinib+TRAS+Al vs TRAS+Al (median PFS 11 vs 5.7 months; $p=0.0064$ ), and lapatinib+AI also showed better PFS compared with TRAS+Al (median PFS 8.3 versus 5.7 months; $p=0.0361$ ). Enhanced ORR, CBR, and OS were also observed in lapatinib+TRAS+Al group. The authors concluded that dual HER2 blockade was effective with tolerable safety profile.

As the immune checkpoint anti-PD-1 antibody pembrolizumab has shown remarkable efficacy in a number of solid tumors, combination of pembrolizumab with trastuzumab for the treatment of trastuzumab-resistant HER2-positive $M B C$ patients $(n=58)$ has recently been assessed in a phase lb/ll study as described in an abstract for the 2017 San Antonio Breast Cancer Symposium ${ }^{30}$; results of the primary (i.e. safety of the combination, and ORR) and secondary (i.e. PFS, duration of response, and OS) endpoints have not been published in public databases.

From our review on trastuzumab clinical trials, we observed that the ORR for trastuzumab monotherapy was below $30 \%$ with the majority of the patients not achieving either PR or CR. As anticipated, combination regimens with trastuzumab demonstrated greater ORR of above $50 \%$ with $25-50 \%$ of the patients achieving pCR i.e. free from invasive disease in the breast and in the axillary lymph nodes at the completion of neoadjuvant treatment.

\section{Pertuzumab}

Pertuzumab (Perjeta) is a newer generation of anti-HER2 mAb for the treatment of HER2-positive MBC and received FDA approval in 2012. Pertuzumab serves as a HER dimerization inhibitor by binding the dimerization arm of HER2 at subdomain II, thereby reducing HER2 intracellular signaling by preventing HER2 from forming heterodimers with other HER receptors and $\mathrm{EGFR}^{31-33}$. As subdomain II does not overlap with other domains or epitopes that bind trastuzumab (subdomain IV), the combination of trastuzumab and pertuzumab could enhance the blockage of HER2-mediated signal transduction ${ }^{34}$

\section{Pertuzumab monotherapy}

In a phase II trial involving HER2-positive locally advanced and MBC patients $(n=29)$ receiving pertuzumab with prior trastuzumab-based therapy, the ORR and CBR were $3.4 \%$ and $10.3 \%$, respectively, with PFS of only 7.1 weeks ${ }^{35}$. Seventeen patients with disease progression continued to receive pertuzumab with the addition of trastuzumab, and the ORR and CBR were $17.6 \%$ and $41.2 \%$, respectively, with improved PFS of 17.4 weeks $^{35}$. The clinical trial showed that pertuzumab monotherapy had lower efficacy compared to addition of trastuzumab.

\section{Pertuzumab in combination with chemotherapy}

In a randomized, open-label phase II clinical trial (NeoSphere) on patients with HER2-positive breast cancer, the patients were subgrouped to receive different treatment regimens as follows: (i) Trastuzumab-docetaxel (group A; $n=107$ ); (ii) Pertuzumab-trastuzumab-docetaxel (group $\mathrm{B}$; $\mathrm{n}=107$ ); (iii) Pertuzumab-trastuzumab (group $\mathrm{C}$; $\mathrm{n}=107$ ); (iv) Pertuzumab-docetaxel (group $\mathrm{D}$; $\mathrm{n}=96)^{36}$. Patients in group $\mathrm{B}$ had the highest and significantly improved PCR of $45.8 \% \quad(n=49)$ compared with $29.0 \%$ in group $A(n=31 ; p=0.0141)$, while groups $C$ and $D$ achieved lower $p C R$ of $16.8 \%$ $(n=18)$ and $24.0 \%(n=23)$, respectively ${ }^{36}$. The best combination in this study was group B (pertuzumab-trastuzumab-docetaxel). The NeoSphere trial that involved large number of patients $(n=417)$ with highly encouraging results led to the accelerated approval of pertuzumab by 
the FDA in September 2013 for the neoadjuvant treatment of high-risk HER2-positive breast cancer as a first-line therapy combined with trastuzumab and chemotherapy.

Other clinical trials have since attempted to examine the efficacy of pertuzumab-trastuzumab combination with other chemotherapy regimens. TRYPHAENA phase II trial involved HER2-positive early breast cancer patients that were randomized to receive six neoadjuvant cycles as follows: (i) Arm A ( $n=72$ ) receiving 5-fluorouracil, epirubicin, cyclophosphamide (FEC) followed by docetaxel (T), with trastuzumab (H) and pertuzumab (P) $(\mathrm{FEC}+\mathrm{H}+\mathrm{P} \times 3 \rightarrow \mathrm{T}+\mathrm{H}+\mathrm{P} \times 3)$; (ii) $\mathrm{Arm}$ $B \quad(n=75)$ receiving $\mathrm{FEC}$ followed by $\mathrm{T}+\mathrm{H}+\mathrm{P}$ $(\mathrm{FEC} \times 3 \rightarrow \mathrm{T}+\mathrm{H}+\mathrm{P} \times 3)$; (iii) Arm $\mathrm{C}$ receiving $\mathrm{T}$, carboplatin, $\mathrm{H}$ with $\mathrm{P}(\mathrm{TCH}+\mathrm{P} \times 6)^{37}$. The $\mathrm{pCR}$ achieved was $61.6 \%, 57.3 \%$ and $66.2 \%$ in Arm A, B and $C$, respectively. Clinical CR was achieved by 50.7\% (Arm A), 28.0\% (Arm B) and 40.3\% (Arm C).

In a phase II trial, patients with HER2-positive MBC with 0-1 prior treatments $(n=51$ and $n=18$ treated in first- and second-line metastatic settings, respectively) were selected. They received treatment combination of paclitaxel weekly, and trastuzumab and pertuzumab every three weeks ${ }^{38}$. The median OS was 44 months $(95 \% \mathrm{Cl}$ : 37.5-not reached [NR]) overall, and 44 months (95\% Cl: 38.3-NR) and 37.5 months $(95 \% \mathrm{Cl}$ : $30.3-$ NR) for patients with 0 and 1 prior metastatic treatment, respectively. Median PFS was 21.4 months (95\% Cl: 14.1-NR) overall, and 25.7 months (95\% Cl: 14.1-NR) and 16.9 months (95\% Cl: 8.5NR) for patients with 0 and 1 prior treatment, respectively. Favorable OS and PFS were achieved when paclitaxel was added weekly into trastuzumab and pertuzumab regimen ${ }^{38}$.

The VELVET phase II trial assessed the efficacy and safety of pertuzumab, trastuzumab and vinorelbinein combination in patients with HER2positive locally advanced or MBC $(n=106)^{39}$. Encouraging results were shown where the ORR was $74.2 \%$ (95\% Cl:63.8-82.9\%) while the median PFS was 14.3 months (95\% Cl:11.2-17.5 months). Another phase II trial was conducted on HER2positive advanced breast cancer patients $(n=30)$ pretreated with taxanes and trastuzumab ${ }^{40}$. The patients were treated with eribulin in combination with pertuzumab and trastuzumab. The ORR was $34.8 \%(\mathrm{n}=23)$, and median PFS was 42.6 weeks $(n=30,95 \% \mathrm{Cl}$ : 20.3-51.9 weeks). Combination of eribulin with anti-HER2 therapy (pertuzumab-trastuzumab) was well tolerated in heavily pretreated patients.

A recent (2018) multicentre, open-label, randomized, phase II trial on HER2-positive MBC elderly patients without previous chemotherapy for metastatic disease showed that dual HER2 blockade with trastuzumab and pertuzumab $(n=39)$ had lower efficacy than dual HER2 blockade plus metronomic oral cyclophosphamide as follows: PFS at 6 months was $46.2 \%$ vs $73.4 \%$; at median follow-up of 20.7 months, median PFS was 5.6 months vs 12.7 months $^{41}$. The authors concluded that trastuzumab and pertuzumab plus metronomic oral cyclophosphamide increased median PFS by seven months with tolerable safety profile, and suggested that this regimen can replace the need for taxane chemotherapy in elderly HER2-positive MBC patients.

In a phase III trial (CLEOPATRA), 808 patients with HER2-positive MBC were assigned to receive pertuzumab-trastuzumab-docetaxel (pertuzumab group) or placebo-trastuzumab-docetaxel (control group) as the first-line treatment ${ }^{42}$. The median PFS was significantly greater in the pertuzumab group (18.5 months) compared with the control group (12.4 months) $(p<0.001)$, and the median OS was significantly improved to 56.5 months compared with 40.8 months in the control group $(p<0.001)^{42}$. This trial further established the improved clinical benefits of the pertuzumabtrastuzumab-docetaxel combination regimen in a phase III setting, consistent with the results shown by the phase II NeoSphere trial.

In another phase III trial (PHEREXA), trastuzumab plus capecitabine with or without pertuzumab was given to patients with HER2-positive MBC who had disease progression during or after trastuzumab-based therapy and received prior a taxane ${ }^{43}$. The patients were divided into arm A ( $n=224$; trastuzumab plus capecitabine) and arm B $(n=228$; pertuzumab plus trastuzumab and capecitabine). Median independent review facility-assessed (IRF) PFS was 28.6 and 25.3 months for arm $A$ and $B$, respectively. The final OS was 28.1 months (arm A) vs 37.3 months (arm B). The addition of pertuzumab to trastuzumab and capecitabine did not significantly improve independent review facility-assessed (IRF) PFS $^{43,44}$.

The APHINITY phase III trial aimed to investigate whether addition of pertuzumab to adjuvant trastuzumab and chemotherapy was efficacious in HER2-positive early breast cancer ${ }^{45}$. The study randomly assigned patients with node-positive or high-risk node-negative HER2-positive breast cancer to receive either pertuzumab $(n=2,400)$ or placebo $(n=2,405)$ with standard adjuvant chemotherapy plus one year of treatment with trastuzumab. The addition of pertuzumab improved the three-year iDFS (94.1\%) compared with the placebo group (93.2\%). This represented an $18 \%$ reduction in the risk of developing invasive disease or death $(\mathrm{HR}=0.81 ; 95 \% \mathrm{Cl}$ : 0.66-1.00; $p=0.045)$. Furthermore, the four-year iDFS were $92.3 \%$ vs $90.6 \%$, and invasive-disease events were observed in $7.1 \%(n=171)$ in the pertuzumab group which was lower than the $8.7 \%$ in the placebo group $(n=210)$. APHINITY is one of the pivotal clinical trials that led to the FDA approval (in December 2017) of pertuzumab in combination with trastuzumab for adjuvant treatment in HER2- 
positive early breast cancer patients at high risk of recurrence.

In a neoadjuvant phase four study (NBRST), HER2positive breast cancer patients $(n=297)$ were enrolled to receive neoadjuvant chemotherapy (NCT) and underwent treatment with trastuzumab $(\mathrm{T})$, or trastuzumab and pertuzumab $(\mathrm{T} / \mathrm{P})^{46}$. Amongst the patients, $60 \%$ received NCT-T and the remaining $40 \%$ received NCT-T/P. Patients treated with NCT-T/P had higher PCR rates than those treated with trastuzumab alone. Addition of pertuzumab to trastuzumab significantly improved the $\mathrm{pCR}$ rate in HER2-positive/ERpositive patients (but not HER2-positive/ERnegative patients) where 33 of 111 patients (29.7\%) reached $\mathrm{pCR}$ with trastuzumab $(95 \% \mathrm{Cl}$ : $22.0-38.8 \%$ ) versus 33 of 73 patients (48\%) with trastuzumab plus pertuzumab $(95 \% \mathrm{Cl}: 36.9-$ $59.2 \%)(p=0.0188)$.

\section{Pertuzumab in combination with chemotherapy-free regimens}

In a phase II trial, the efficacy and safety profile of the pertuzumab-trastuzumab combination was assessed in patients with HER2-positive breast cancer $(n=66)$ who had disease progression during prior trastuzumab-based therapy ${ }^{47}$. The ORR was 24.2\%, CBR was $50 \%$ (CR: $7.6 \%$; $n=5$, PR: $16.7 \%$; $n=11)$, and SD of six months was $25.8 \%(n=17)$. Median PFS was 5.5 months, and this combination was well tolerated. In a recent phase II trial (NAPHER2) of multi-agents regimen targeting ER (fulvestrant), HER2 (trastuzumab and pertuzumab), and RB1 (palbociclib, an inhibitor of CDK4/6 approved for treatment of breast cancer) ${ }^{48,49}$ in HER2-positive and ER-positive breast cancer $(n=30)$, a clinical ORR immediately before surgery was achieved by $97 \%(n=29)$ of the patients ${ }^{50}$. At surgery, $27 \%(n=8)$ patients had a PCR in breast and axillary nodes. These encouraging results have prompted the authors to currently investigate whether HER2-ER-RB1 triple block is effective in ER-positive breast cancer patients without HER2 amplification or overexpression.

\section{Trastuzumab emtansine (T-DM1)}

Trastuzumab emtansine or T-DM1 (Kadcyla) was the first ADC approved for cancer therapy in 2013. T-DM1 was developed to improve the efficacy of breast cancer treatment in patients with previously treated HER2-positive MBC and those who developed trastuzumab resistance ${ }^{51}$. The HER2-targeting ADC consists of the conjugation between trastuzumab with the cytotoxic agent emtansine (DM1, derivative of maytansine) via a non-reducible thioether linker ${ }^{52}$. The $A D C$ linker tethers the antibody to a cytotoxic agent which enables stable circulation of the cytotoxin in the form of a prodrug ${ }^{53}$. The functions of the linker include modulation of cytotoxin release in tumor cells, overcoming multidrug resistance, and enhancing tumor penetration.
T-DM1 binds to HER2-expressing cells with the common affinity of trastuzumab and selectively delivers DM1 to HER2-positive tumor cells via endocytosis, thus maximizing the therapeutic potential of DM1 with minimal off-target effects ${ }^{31,54}$. DM1-containing metabolites eventually inhibit microtubule assembly, causing apoptosis in HER2-overexpressed cancer cells ${ }^{52,55}$. It also facilitates antibody-dependent cellular cytotoxicity (ADCC), inhibits HER2 extracellular domain shedding, and inhibits the PI3K signaling pathway ${ }^{54,56}$.

\section{T-DM1 monotherapy}

Three phase I studies had demonstrated the therapeutic potential and tolerability of T-DM1 monotherapy, and established the optimal dosage of $3.6 \mathrm{mg} / \mathrm{kg}$ every 3 weeks ${ }^{57-59}$. A single-arm phase II study (TDM4258g) on HER2-positive MBC patients $(n=112)$ who received prior HER2targeted therapies or chemotherapy showed that patients treated with the established $3.6 \mathrm{mg} / \mathrm{kg}$ of T-DM1 every 3 weeks had median PFS of 4.6 months (95\% Cl: $3.9-8.6$ months), and $25.9 \%$ $(n=29)$ of the patients achieved ORR, 37.5\% $(n=42)$ patients achieving objective responses including $3.6 \%(n=4)$ experienced $C^{60}$.

In a pivotal phase III trial (EMILIA) assessing HER2positive advanced breast cancer previously treated with trastuzumab and a taxane $(n=991)$, the patients were given the standard $3.6 \mathrm{mg} / \mathrm{kg}$ every 3 weeks with dose delays, reductions or discontinuations due to toxic effects were also conducted $^{61}$. The median PFS and OS with T-DM1 $(n=495)$ was significantly longer than the group receiving lapatinib plus capecitabine $(L+C ; n=496)$ (median PFS: 9.6 vs 6.4 months, $p<0.001$; median OS: 30.9 vs 25.1 months, $p<0.001)$. The ORR was also significantly higher in T-DM1 than $L+C(43.6 \%$ vs $30.8 \% ; p<0.001$ ), while the rates of grade $\geq 3$ adverse events (AEs) were higher in $\mathrm{L}+\mathrm{C}$ than $\mathrm{T}$ DM1 (57\% vs $41 \%)$. As the trial reported superior clinical benefits with less toxicity, it led to the approval of T-DM1 use by FDA in February 2013.

The results of improved OS with T-DM1 in the EMILIA trial were also consistent with those of another phase III (TH3RESA) clinical trial conducted on patients with HER2positive advanced breast cancer who were previously treated with trastuzumab, lapatinib and a taxane ${ }^{54}$. Patients were assigned to receive T-DM1 $(n=404)$ versus treatment of physician's choice $(n=198)$, and OS was significantly longer in T-DM1 (22.7 months) versus treatment of physician's choice (15.8 months; $p=0.0007)$. The favorable safety profile was also maintained despite the mean treatment duration with T-DM1 was almost twice as long compared with treatments of physician's choice.

\section{T-DM1 in combination with chemotherapy}

A phase II trial evaluated the safety of T-DM1 plus paclitaxel combination with or without 
pertuzumab in HER2-positive advanced breast cancer patients $(n=44)^{62}$. A total of $51.2 \%$ received $\geq 12$ paclitaxel doses within 15 weeks. Among the 42 patients with measurable disease, ORR was $50 \%$ and the CBR was $56.8 \%$. No pharmacokinetic interactions were observed between T-DM1 and paclitaxel combination. A subsequent phase Ib/lla study assessed the feasibility of T-DM1 plus docetaxel in patients with HER2-positive MBC $(n=25)$ and T-DM1 plus docetaxel with or without pertuzumab in patients with HER2-positive locally advanced breast cancer (LABC; part 2; $n=73)^{63}$. The resulting MTD for T-DM1 was $3.6 \mathrm{mg} / \mathrm{kg}$ while docetaxel was $60 \mathrm{mg} / \mathrm{m}^{2}$. In MBC patients, the ORR was $80 \%$ with median PFS of 13.8 months while the PCR rate in LABC patients was $60.3 \%$, while drugdrug interaction between T-DM1 and docetaxel was of low risk according to pharmacokinetic analyses. However, the authors reported that almost half of the patients had AEs that necessitated dose reductions in these T-DM1 combination regimens.

\section{T-DM1 in combination with chemotherapy-free regimens}

In a phase II trial of T-DM1 and pertuzumab combination treatment in patients with HER2positive $\mathrm{MBC}^{64}, 21$ patients in the first-line setting and 43 patients in second-line setting (advanced $\mathrm{MBC}$ ) were enrolled. The ORR and median PFS was $57 \%$ and 7.7 months for first-line patients, while $33 \%$ and 5.5 months for advanced $M B C$, respectively. The authors concluded that T-DM1 and pertuzumab can be combined at full doses without unexpected toxicities.

Phase III trial (MARIANNE) was conducted on HER2positive advanced breast cancer patients $(n=1,095)$ with no prior therapy for advanced disease ${ }^{65}$. The patients were randomly assigned to receive T-DM1 plus placebo, T-DM1 plus pertuzumab, or trastuzumab plus a taxane (control group). T-DM1 in combination with other agents showed less clinical benefit than the control group but better tolerability and lesser side effects. The ORR was 59.7\% (T-DM1 plus placebo), 64.2\% (T-DM1 plus pertuzumab), and $67.9 \%$ (control group).

The KRISTINE clinical trial (phase III) was conducted by assigning patients with HER2positive breast cancer stage II-III to receive either neoadjuvant treatment with T-DM1 plus pertuzumab $(n=223)$ or docetaxel, carboplatin, trastuzumab plus pertuzumab (DCTP; $n=221)^{66}$. The pCR of $44.4 \%$ was lower in the T-DM1 group $(n=9)$ vs $55.7 \% \quad(n=123)$ in the DCTP group $(p=0.016)$. However, patients in the DCTP group experienced more frequent and serious AEs than in the T-DM1 group, indicating that T-DM1 plus pertuzumab alone represents a potential neoadjuvant treatment to limit the occurrence of serious AEs. Summary of the phase II/III trials discussed in this paper are presented in Table $1 \mathrm{~A}$ and Table $1 \mathrm{~B}$ (trastuzumab), Table $2 \mathrm{~A}$ and Table 2B (pertuzumab), and, Table $3 \mathrm{~A}$ and Table $3 \mathrm{~B}$ ( $\mathrm{T}$ DM1). Ongoing phase II and III clinical trials of trastuzumab, pertuzumab and T-DM1 not discussed in this review are presented in Table 4.

\section{Chemotherapy of choice for anti-HER2 therapeutic antibodies}

Several phase II and III trials have demonstrated that pertuzumab plus trastuzumab in combination with chemotherapy regimens confer enhanced clinical outcomes compared with pertuzumab plus trastuzumab alone, or antibody monotherapy, for metastatic or advanced HER2-positive breast cancer patients (Tables 1 and 2). Moreover, multiple clinical trials have shown that although T-DM1 plus pertuzumab without chemotherapy has better safety profile, the combination confers lower efficacy than chemotherapy-containing regimens (Table 3 ). Therefore in this section, we suggest the optimal chemotherapy of choice for each of the three anti-HER2 therapeutic antibodies. Studies involving treatment-naïve HER2-positive breast cancer patients only were included in the comparison and discussion. This was due to different regimens were used in pretreatment of HER2-positive breast cancer patients and such heterogeneity hindered direct comparisons (Tables 1-3). Trastuzumab plus paclitaxel was the commonly used chemotherapycontaining regimen for MBC or stage II/III HER2 positive treatment-naïve breast cancer patients ${ }^{22}$ ${ }^{24}$. In these phase II and III studies, trastuzumab and paclitaxel combined with either carboplatin ${ }^{23}$ or lapatinib ${ }^{24}$ showed improvements in the ORR or $\mathrm{pCR}$. For trastuzumab in combination with chemotherapy-free regimen, trastuzumab plus lapatinib also showed markedly higher $\mathrm{PCR}$ (51.3\%) compared with lapatinib $(24.7 \%)$ or trastuzumab alone $(29.5 \%)^{28}$. These suggest that combination of trastuzumab with lapatinib, with or without paclitaxel, represents the optimal combination regimen containing trastuzumab.

In terms of pertuzumab, dual anti-HER2 therapy (pertuzumab and trastuzumab) combined with chemotherapy has shown improved efficacy compared with either antibody alone in terms of $\mathrm{pCR}^{36,46}, \mathrm{PFS}^{41,42}$, and $\mathrm{OS}^{42-44}$. In treatment-naïve breast cancer patients treated with trastuzumab and pertuzumab, combination with chemotherapies including 5-fluorouracil, epirubicin and cyclophosphamide followed by docetaxel and both antibodies yielded superior PCR (61.6\%) compared with other chemotherapycontaining regimens such as docetaxel only ${ }^{36}$ and neoadjuvant chemotherapy ${ }^{46}$. In terms of pertuzumab in combination with chemotherapyfree regimen, only one regimen (pertuzumab plus trastuzumab, palbociclib and fulvestrant) has been assessed in treatment-naïve HER2-positive breast cancer patients with promising ORR and $\mathrm{pCR}^{50}$. 
Table 1A: Summary of phase II/III trials of trastuzumab discussed in this review

\begin{tabular}{|c|c|c|c|c|c|c|}
\hline Antibody & Trial ID/ Authors & Phase & Patient Population & Pre-treatment & Treatment & Outcomes \\
\hline \multirow{5}{*}{$\begin{array}{l}\text { Trastuzumab } \\
\text { monotherapy }\end{array}$} & Baselga et al. ${ }^{16}$ & II & HER2-positive MBC $(\mathrm{n}=43)$ & No & Trastuzumab monotherapy & ORR: $11 \% ;$ CR: $2.3 \%$ \\
\hline & Cobleigh et al. ${ }^{17}$ & II & HER2-positive MBC $(\mathrm{n}=222)$ & No & Trastuzumab monotherapy & $\begin{array}{l}\text { CR: } 3.6 \% \text {; PR: } 11.7 \% \text {; ORR: } \\
15 \%\end{array}$ \\
\hline & Vogel et al. ${ }^{18}$ & II & $\begin{array}{l}\text { HER2-overexpressing MBC } \\
(\mathrm{n}=114)\end{array}$ & No & Trastuzumab monotherapy & $\begin{array}{l}\text { ORR: } 26 \% \text {; CR: } 6.1 \% \text {; PR: } \\
\text { 20.2\%; Response rate: } 35 \% \text {; } \\
\text { CBR: } 48 \%\end{array}$ \\
\hline & Baselga et al. ${ }^{19}$ & II & HER2-positive MBC $(\mathrm{n}=105)$ & No & Trastuzumab monotherapy & $\begin{array}{l}\text { ORR: } 19 \% \text {; CR: } 1.9 \% \text {; PR: } \\
\text { 17.1\%; CBR: } 33 \% \text { and } \\
\text { median time to } \\
\text { progression: } 3.4 \text { months }\end{array}$ \\
\hline & $\begin{array}{l}\text { NCT00045032 } \\
\quad(\text { HERA })^{20}\end{array}$ & III & $\begin{array}{l}\text { HER2-positive early breast } \\
\text { cancer }(n=5,102)\end{array}$ & $\begin{array}{l}\text { Adjuvant } \\
\text { chemotherapy }\end{array}$ & $\begin{array}{l}1 \text { year of trastuzumab/ } 2 \\
\text { years of trastuzumab/ } \\
\text { observation }\end{array}$ & $\begin{array}{l}10 \text {-year DFS: } 69 \% \text { vs } 69 \% \text { vs } \\
63 \%\end{array}$ \\
\hline \multirow{5}{*}{$\begin{array}{l}\text { Trastuzumab in } \\
\text { combination } \\
\text { with } \\
\text { chemotherapy }\end{array}$} & NCT00542451 & II & $\begin{array}{l}\text { HER2-positive breast } \\
\text { cancer }(n=406)\end{array}$ & No & Trastuzumab + paclitaxel & iDFS: $98.7 \%$ \\
\hline & Robert et al. ${ }^{23}$ & II & $\begin{array}{l}\text { HER2-overexpressing MBC } \\
(n=196)\end{array}$ & No & $\begin{array}{l}\text { Trastuzumab + paclitaxel }+ \\
\text { carboplatin/ trastuzumab + } \\
\text { paclitaxel }\end{array}$ & $\begin{array}{l}\text { ORR: } 52 \% \text { vs } 36 \% \text {; } \\
\text { Median PFS: } 10.7 \text { months } \\
\text { vs } 7.1 \text { months }\end{array}$ \\
\hline & $\begin{array}{l}\text { NCT00915018 } \\
\left(^{(N E f E R T-T)}\right)^{22}\end{array}$ & II & $\begin{array}{l}\text { Recurrent and/or HER2- } \\
\text { positive MBC }(n=479)\end{array}$ & No & $\begin{array}{l}\text { Trastuzumab + paclitaxel/ } \\
\text { neratinib + trastuzumab }\end{array}$ & $\begin{array}{l}\text { ORR: } 77.6 \% \text { vs } 74.8 \% \text {; CBR: } \\
85.2 \% \text { CS } 88.4 \% \text {; Median } \\
\text { PFS: } 12.9 \text { months vs } 12.9 \\
\text { months }\end{array}$ \\
\hline & $\begin{array}{l}\text { NCT00770809 } \\
(\text { CALGB40601) }\end{array}$ & III & $\begin{array}{l}\text { Stage II to III HER2-positive } \\
\text { breast cancer }(\mathrm{n}=305)\end{array}$ & No & $\begin{array}{l}\text { Paclitaxel + trastuzumab/ } \\
\text { paclitaxel + trastuzumab + } \\
\text { lapatinib/ paclitaxel + } \\
\text { lapatinib }\end{array}$ & pCR: $46 \%$ vs $56 \%$ vs $32 \%$ \\
\hline & $\begin{array}{l}\text { NCT01125566 } \\
(\text { LUX-Breast 1) })^{25}\end{array}$ & III & $\begin{array}{l}\text { HER2-overexpressing MBC } \\
(n=508)\end{array}$ & Trastuzumab & $\begin{array}{l}\text { Afatinib + vinorelbine/ } \\
\text { trastuzumab + vinorelbine }\end{array}$ & $\begin{array}{l}\text { Median PFS: } 5.5 \text { months vs } \\
5.6 \text { months }\end{array}$ \\
\hline
\end{tabular}

objective response rate, $p C R$ : Pathological complete response, PFS: Progression-free survival, PR: Partial response 
Table 1B: Summary of phase II/III trials of trastuzumab discussed in this review

\begin{tabular}{|c|c|c|c|c|c|c|}
\hline Antibody & Trial ID/ Authors & Phase & Patient Population & Pre-treatment & Treatment & Outcomes \\
\hline \multirow{3}{*}{$\begin{array}{l}\text { Trastuzumab } \\
\text { in combination } \\
\text { with } \\
\text { chemotherapy- } \\
\text { free regimen }\end{array}$} & Pistilli et al. ${ }^{27}$ & II & $\begin{array}{l}\text { HER2-positive advanced } \\
\text { breast cancer patients } \\
(n=50)\end{array}$ & $\begin{array}{l}\text { HER2-targeted } \\
\text { therapy, } \\
\text { chemotherapy }\end{array}$ & Buparlisib + trastuzumab & ORR: $10 \%$ \\
\hline & $\begin{array}{l}\text { NCT00553358 } \\
\left(_{\text {NeoALTTO })^{28}}\right.\end{array}$ & III & $\begin{array}{l}\text { HER2-positive primary } \\
\text { breast cancer }(n=455)\end{array}$ & No & $\begin{array}{l}\text { Lapatinib/ trastuzumab } \\
\text { monotherapy/ trastuzumab + } \\
\text { lapatinib }\end{array}$ & pCR: $24.7 \%$ vs $29.5 \%$ vs $51.3 \%$ \\
\hline & $\begin{array}{l}\text { Johnston et al. } \\
\text { (ALTERNA-TIVE) }^{29}\end{array}$ & III & $\begin{array}{l}\text { HER2-positive/HR- } \\
\text { positive MBC }(n=355)\end{array}$ & $\begin{array}{l}\text { Endocrine } \\
\text { treatment and } \\
\text { prior } \\
\text { neo(adjuvant)/ } \\
\text { first-line TRAS } \\
\text { plus } \\
\text { chemotherapy }\end{array}$ & $\begin{array}{l}\text { Lapatinib + trastuzumab } \\
\text { (TRAS) + aromatase inhibitor } \\
(\mathrm{Al}) / \mathrm{TRAS}+\mathrm{Al} / \text { lapatinib + Al }\end{array}$ & $\begin{array}{l}\text { Median PFS: } 11 \text { months vs } 8.3 \\
\text { months vs } 5.7 \text { months }\end{array}$ \\
\hline
\end{tabular}

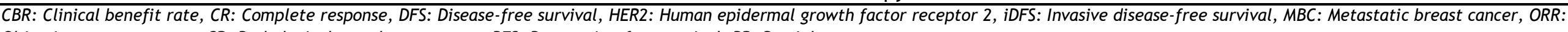

objective response rate, $p C R$ : Pathological complete response, PFS: Progression-free survival, PR: Partial response 
Table 2A: Summary of phase II/III trials of pertuzumab discussed in this review

\begin{tabular}{|c|c|c|c|c|c|c|}
\hline Antibody & $\begin{array}{l}\text { Trial ID/ } \\
\text { Authors }\end{array}$ & Phase & Patient Population & Pre-treatment & Treatment & Outcomes \\
\hline $\begin{array}{l}\text { Pertuzumab } \\
\text { monotherapy }\end{array}$ & NCT0030189935 & II & $\begin{array}{l}\text { HER2-positive } \\
\text { advanced or MBC } \\
(n=29)\end{array}$ & $\begin{array}{l}\text { Trastuzumab } \\
\text { based therapy }\end{array}$ & $\begin{array}{l}\text { Pertuzumab monotherapy/ } \\
\text { pertuzumab + trastuzumab }\end{array}$ & $\begin{array}{l}\text { ORR: } 3.4 \% \text { vs } 17.6 \% \\
\text { CBR: } 10.3 \% \text { vs } 41.2 \% \\
\text { PFS: } 7.1 \text { weeks vs } 17.4 \text { weeks }\end{array}$ \\
\hline \multirow[t]{5}{*}{$\begin{array}{l}\text { Pertuzumab in } \\
\text { combination } \\
\text { with } \\
\text { chemotherapy }\end{array}$} & $\begin{array}{l}\text { NCT00545688 } \\
\text { (NeoSphere) }^{36}\end{array}$ & II & $\begin{array}{l}\text { HER2-positive breast } \\
\text { cancer }(n=417)\end{array}$ & No & $\begin{array}{l}\text { Trastuzumab + docetaxel/ } \\
\text { pertuzumab + trastuzumab + } \\
\text { docetaxel/ pertuzumab + } \\
\text { trastuzumab/ pertuzumab + } \\
\text { docetaxel }\end{array}$ & $\begin{array}{l}\text { pCR: } 29.0 \% \text { vs } 45.8 \% \text { vs } 16.8 \% \\
\text { vs } 24.0 \%\end{array}$ \\
\hline & $\begin{array}{l}\text { Schneeweiss et al. } \\
\text { (TRYPHAENA) }^{37}\end{array}$ & II & $\begin{array}{l}\text { HER2-positive early } \\
\text { breast cancer }(n=225)\end{array}$ & No & $\begin{array}{l}\text { 5-fluorouracil, epirubicin, } \\
\text { cyclophosphamide [FEC] }+ \\
\text { trastuzumab }[\mathrm{H}]+\text { pertuzumab } \\
{[\mathrm{P}] \times 3 \rightarrow \text { docetaxel }[\mathrm{T}]+\mathrm{H}+\mathrm{P}} \\
\times 3 / \mathrm{FEC} \times 3 \rightarrow \mathrm{T}+\mathrm{H}+\mathrm{P} \times 3 / \mathrm{T} \\
+ \text { carboplatin }+\mathrm{H}[\mathrm{TCH}]+\mathrm{P} \\
\times 6)\end{array}$ & $\begin{array}{l}\text { pCR: } 61.6 \% \text { vs } 57.3 \% \text { vs } 66.2 \% \\
\text { ORR: } 89.6 \%-94.7 \% \\
\text { CR: } 50.7 \% \text { vs } 28.0 \% \text { vs } 40.3 \%\end{array}$ \\
\hline & Smyth et al. ${ }^{38}$ & II & $\begin{array}{l}\text { HER2-positive MBC } \\
(\mathrm{n}=69)\end{array}$ & $\begin{array}{l}\text { Adjuvant } \\
\text { trastuzumab, } \\
\text { lapatinib, ET, } \\
\text { chemotherapy }\end{array}$ & $\begin{array}{l}\text { Pertuzumab + trastuzumab }+ \\
\text { paclitaxel }\end{array}$ & $\begin{array}{l}\text { Median OS: } 44 \text { months } \\
\text { Median PFS: } 21.4 \text { months }\end{array}$ \\
\hline & $\begin{array}{l}\text { NCT01565083 } \\
\text { (VELVET) }^{39}\end{array}$ & II & $\begin{array}{l}\text { HER2-positive locally } \\
\text { advanced or MBC } \\
(n=89)\end{array}$ & $\begin{array}{l}\text { Taxane, } \\
\text { antracycline, } \\
\text { trastuzumab, } \\
\text { bevacizumab }\end{array}$ & $\begin{array}{l}\text { Pertuzumab + trastuzumab + } \\
\text { vinorelbine }\end{array}$ & $\begin{array}{l}\text { ORR: } 74.2 \% \\
\text { Median PFS: } 14.3 \text { months }\end{array}$ \\
\hline & UMIN00001237540 & II & $\begin{array}{l}\text { HER2-positive } \\
\text { advanced breast } \\
\text { cancer patients } \\
(\mathrm{n}=30)\end{array}$ & $\begin{array}{l}\text { Taxanes and } \\
\text { trastuzumab }\end{array}$ & $\begin{array}{l}\text { Eribulin + pertuzumab + } \\
\text { trastuzumab. }\end{array}$ & $\begin{array}{l}\text { ORR: } 34.8 \% \\
\text { Median PFS: } 42.6 \text { weeks }\end{array}$ \\
\hline
\end{tabular}

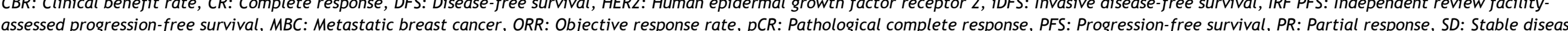


Table 2B: Summary of phase II/III trials of pertuzumab discussed in this review

\begin{tabular}{|c|c|c|c|c|c|c|}
\hline Antibody & $\begin{array}{l}\text { Trial ID/ } \\
\text { Authors }\end{array}$ & Phase & Patient Population & $\begin{array}{c}\text { Pre- } \\
\text { treatment }\end{array}$ & Treatment & Outcomes \\
\hline \multirow[t]{5}{*}{$\begin{array}{l}\text { Pertuzumab in } \\
\text { combination with } \\
\text { chemotherapy }\end{array}$} & NCT01597414 41 & III & $\begin{array}{l}\text { HER2-positive MBC } \\
(\mathrm{n}=39)\end{array}$ & Yes & $\begin{array}{l}\text { Trastuzumab + pertuzumab/ } \\
\text { Trastuzumab + pertuzumab + } \\
\text { metronomic oral } \\
\text { cyclophosphamide }\end{array}$ & $\begin{array}{l}\text { Median PFS was } 5.6 \text { months vs } 12.7 \\
\text { months }\end{array}$ \\
\hline & $\begin{array}{l}\text { NCT01026142 } \\
\left(^{\text {PHEREXA) }}{ }^{43,44}\right.\end{array}$ & III & $\begin{array}{l}\text { HER2-positive } M B C \\
(\mathrm{n}=452)\end{array}$ & $\begin{array}{l}\text { Trastuzumab- } \\
\text { based therapy } \\
\text { and taxane }\end{array}$ & $\begin{array}{l}\text { Trastuzumab + capecitabine } \\
\text { pertuzumab + trastuzumab + } \\
\text { capecitabine }\end{array}$ & $\begin{array}{l}\text { IRF PFS: } 28.6 \text { months vs } 25.3 \text { months } \\
\text { OS: } 28.1 \text { months vs } 37.3 \text { months }\end{array}$ \\
\hline & $\begin{array}{l}\text { NCT00567190 } \\
(\text { CLEOPATRA })^{42}\end{array}$ & III & $\begin{array}{l}\text { HER2-positive } M B C \\
(\mathrm{n}=808)\end{array}$ & Trastuzumab & $\begin{array}{l}\text { Pertuzumab + trastuzumab + } \\
\text { docetaxel/ placebo + } \\
\text { trastuzumab + docetaxel }\end{array}$ & $\begin{array}{l}\text { PFS: } 18.5 \text { months vs } 12.4 \text { months } \\
\text { Median OS: } 56.5 \text { months vs } 40.8 \\
\text { months }\end{array}$ \\
\hline & $\begin{array}{l}\text { NCT01358877 } \\
\text { (APHINITY) }^{45}\end{array}$ & III & $\begin{array}{l}\text { HER2-positive breast } \\
\text { cancer }(n=4,805)\end{array}$ & No & $\begin{array}{l}\text { Pertuzumab + trastuzumab } \\
\text { pertuzumab + placebo }\end{array}$ & $\begin{array}{l}3 \text {-year rate of iDFS: } 94.1 \% \text { vs } 93.2 \% \\
\text { Invasive-disease events: } 7.1 \% \text { vs } 8.7 \%\end{array}$ \\
\hline & $\begin{array}{l}\text { NCT01479101 } \\
\text { (NBRST) }^{46}\end{array}$ & IV & $\begin{array}{l}\text { HER2-positive breast } \\
\text { cancer patients } \\
(\mathrm{n}=297)\end{array}$ & No & $\begin{array}{l}\text { Neoadjuvant chemotherapy } \\
\text { (NCT) + trastuzumab / NCT+ } \\
\text { trastuzumab + pertuzumab }\end{array}$ & pCR: $29.7 \%$ vs $48.0 \%$ \\
\hline \multirow{2}{*}{$\begin{array}{l}\text { Pertuzumab in } \\
\text { combination with } \\
\text { chemotherapy-free } \\
\text { regimen }\end{array}$} & $\begin{array}{l}\text { NCT02530424 } \\
\left(^{\text {NA-PHER2) }}{ }^{50}\right.\end{array}$ & II & $\begin{array}{l}\text { HER2-positive breast } \\
\text { cancer }(n=30)\end{array}$ & No & $\begin{array}{l}\text { Trastuzumab + pertuzumab + } \\
\text { palbociclib + fulvestrant }\end{array}$ & $\begin{array}{l}\text { ORR (before surgery): } 97 \% ; \text { pCR (at } \\
\text { surgery): } 27 \%\end{array}$ \\
\hline & $\begin{array}{l}\text { Baselga et } \\
\quad \text { al. }^{47}\end{array}$ & II & $\begin{array}{l}\text { HER2-positive breast } \\
\text { cancer }(n=66)\end{array}$ & $\begin{array}{l}\text { Trastuzumab- } \\
\text { based therapy }\end{array}$ & Pertuzumab + trastuzumab & $\begin{array}{l}\text { ORR: } 24.2 \% \text {; CBR: } 50 \% \text {; CR: } 7.6 \% \text {; } \\
\text { PR:16.7\%; SD: } 25.8 \%\end{array}$ \\
\hline
\end{tabular}

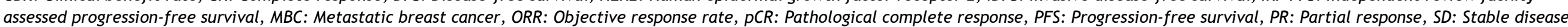


Table 3A: Summary of phase II/III trials of T-DM1 discussed in this review

\begin{tabular}{|c|c|c|c|c|c|c|}
\hline Antibody & Trial ID/ Authors & Phase & Patient Population & Pre-treatment & Treatment & Outcomes \\
\hline \multirow[t]{7}{*}{$\begin{array}{l}\text { T-DM1 } \\
\text { monotherapy }\end{array}$} & $\begin{array}{l}\text { NCT00509769 } \\
\left(^{\text {TDM4258g) }}\right.\end{array}$ & II & $\begin{array}{l}\text { HER2-positive MBC } \\
(n=112)\end{array}$ & $\begin{array}{l}\text { HER2-targeted } \\
\text { therapies or } \\
\text { chemotherapy }\end{array}$ & T-DM1 monotherapy & $\begin{array}{l}\text { ORR: } 25.9 \% \text {; Median PFS: } 4.6 \\
\text { months; objective } \\
\text { responses: } 37.5 \% \text {; CR: } 3.6 \%\end{array}$ \\
\hline & $\begin{array}{l}\text { NCT00679341 } \\
(\text { TDM4450) }\end{array}$ & II & $\begin{array}{l}\text { HER2-positive MBC } \\
(\mathrm{n}=137)\end{array}$ & $\begin{array}{l}\text { Taxane, } \\
\text { trastuzumab, } \\
\text { antracycline }\end{array}$ & $\begin{array}{l}\text { T-DM1 monotherapy/ } \\
\text { trastuzumab + docetaxel }\end{array}$ & $\begin{array}{l}\text { Median PFS: } 14.2 \text { months vs } \\
9.2 \text { months; ORR: } 64.2 \% \text { vs } \\
58.0 \%\end{array}$ \\
\hline & Krop et al. ${ }^{70}$ & II & $\begin{array}{l}\text { HER2-positive MBC } \\
(n=110)\end{array}$ & $\begin{array}{l}\text { Trastuzumab, } \\
\text { lapatinib, an } \\
\text { anthracycline, a } \\
\text { taxane, and } \\
\text { capecitabine }\end{array}$ & T-DM1 monotherapy & $\begin{array}{l}\text { ORR: } 34.5 \% \text {; CBR: } 48.2 \% \text {; } \\
\text { median PFS: } 6.9 \text { months; }\end{array}$ \\
\hline & 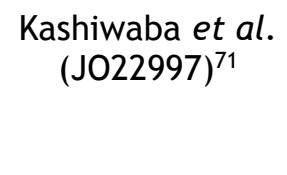 & II & $\begin{array}{l}\text { HER2-positive } \\
\text { inoperable locally } \\
\text { advanced/recurrent or } \\
\text { MBC }(n=73)\end{array}$ & $\begin{array}{l}\text { Chemotherapy } \\
\text { regimen and } \\
\text { trastuzumab }\end{array}$ & T-DM1 monotherapy & $\begin{array}{l}\text { ORR: } 38.4 \% \text {; Median PFS: } 5.6 \\
\text { months; Median OS: } 30.5 \\
\text { months }\end{array}$ \\
\hline & $\begin{array}{l}\text { NCT01745965 } \\
(\text { ADAPT })^{72}\end{array}$ & II & $\begin{array}{l}\text { HER2-positive/HR- } \\
\text { positive early breast } \\
\text { cancer patients }(n=375)\end{array}$ & No & $\begin{array}{l}\text { T-DM1 / T-DM1 + endocrine } \\
\text { therapy / trastuzumab + } \\
\text { endocrine therapy }\end{array}$ & pCR: $41.0 \%$ vs $41.5 \%$ vs $15.1 \%$ \\
\hline & $\begin{array}{l}\text { NCT01419197 } \\
(\text { TH3RESA })^{54}\end{array}$ & III & $\begin{array}{l}\text { HER2-positive advanced } \\
\text { breast cancer }(n=602)\end{array}$ & $\begin{array}{l}\text { Trastuzumab, } \\
\text { lapatinib and a } \\
\text { taxane }\end{array}$ & T-DM1/ physician's choice & $\begin{array}{l}\text { OS: } 22.7 \text { months vs } 15.8 \\
\text { months }\end{array}$ \\
\hline & $\begin{array}{l}\text { NCT00829166 } \\
(\text { EMILIA })^{61}\end{array}$ & III & $\begin{array}{l}\text { HER2-positive advanced } \\
\text { breast cancer }(n=991)\end{array}$ & $\begin{array}{l}\text { Trastuzumab } \\
\text { and a taxane }\end{array}$ & $\begin{array}{l}\text { T-DM1/ lapatinib + } \\
\text { capecitabine }\end{array}$ & $\begin{array}{l}\text { PFS: } 9.6 \text { months vs } 6.4 \\
\text { months } \\
\text { OS: } 30.9 \text { months vs } 25.1 \\
\text { months } \\
\text { ORR: } 43.6 \% \text { vs } 30.8 \%\end{array}$ \\
\hline
\end{tabular}


Table 3B: Summary of phase II/III trials of T-DM1 discussed in this review

\begin{tabular}{|c|c|c|c|c|c|c|}
\hline Antibody & Trial ID/ Authors & Phase & Patient Population & Pre-treatment & Treatment & Outcomes \\
\hline \multirow[t]{2}{*}{$\begin{array}{l}\text { T-DM1 in } \\
\text { combination } \\
\text { with } \\
\text { chemotherapy }\end{array}$} & NCT0095166562 & II & $\begin{array}{l}\text { HER2-positive advanced } \\
\text { breast cancer patients } \\
(n=44)\end{array}$ & $\begin{array}{l}\text { Taxane, } \\
\text { trastuzumab, } \\
\text { antracycline, } \\
\text { lapatinib }\end{array}$ & $\begin{array}{l}\text { T-DM1 + paclitaxel + } \\
\text { pertuzumab }\end{array}$ & ORR: 50\%; CBR: $56.8 \%$ \\
\hline & NCT00934856 63 & II & $\begin{array}{l}\text { HER2-positive } M B C \text { and } \\
\text { locally advanced breast } \\
\text { cancer }(n=98)\end{array}$ & $\begin{array}{l}\text { Taxane, } \\
\text { trastuzumab }\end{array}$ & $\begin{array}{l}\text { T-DM1 + docetaxel + } \\
\text { pertuzumab }\end{array}$ & $\begin{array}{l}\text { ORR: } 80 \% \text {; median PFS: } 13.8 \text { months; } \\
\text { pCR: } 60.3 \%\end{array}$ \\
\hline \multirow[t]{3}{*}{$\begin{array}{l}\text { T-DM1 in } \\
\text { combination } \\
\text { with } \\
\text { chemotherapy- } \\
\text { free regimen }\end{array}$} & NCT0087597964 & II & HER2-positive MBC $(n=64)$ & $\begin{array}{l}\text { Taxane, } \\
\text { trastuzumab, } \\
\text { antracycline, } \\
\text { lapatinib, } \\
\text { capecitabine }\end{array}$ & T-DM1 + pertuzumab & $\begin{array}{l}\text { ORR: } 57 \% \text { (first line) vs } 33 \% \text { (second } \\
\text { line) } \\
\text { PFS: } 7.7 \text { months (first line) vs } 5.5 \\
\text { months (second line) }\end{array}$ \\
\hline & $\begin{array}{l}\text { NCT01120184 } \\
\left(_{\text {MARIANNE) }}^{65}\right.\end{array}$ & III & $\begin{array}{l}\text { HER2-positive, advanced } \\
\text { breast cancer patients } \\
(n=1,095)\end{array}$ & $\begin{array}{l}\text { Taxane, } \\
\text { trastuzumab, } \\
\text { antracycline }\end{array}$ & $\begin{array}{l}\text { T-DM1 + placebo/ T-DM1 + } \\
\text { pertuzumab/ trastuzumab + } \\
\text { a taxane (control) }\end{array}$ & $\begin{array}{l}\text { PFS: } 14.1 \text { months vs } 15.2 \text { months vs } \\
13.7 \text { months } \\
\text { ORR: } 59.7 \% \text { vs } 64.2 \% \text { vs } \\
67.9 \%\end{array}$ \\
\hline & $\begin{array}{l}\text { NCT02131064 } \\
\text { (KRISTINE) }^{66}\end{array}$ & III & $\begin{array}{l}\text { HER2-positive breast } \\
\text { cancer stage II III ( } n=444)\end{array}$ & No & $\begin{array}{l}\text { T-DM1 + pertuzumab/ } \\
\text { docetaxel + carboplatin + } \\
\text { trastuzumab + pertuzumab }\end{array}$ & pCR: $44.4 \%$ vs $55.7 \%$ \\
\hline
\end{tabular}

CBR: Clinical benefit rate, CR: Complete response, DFS: Disease-free survival, HER2: Human epidermal growth factor receptor 2, iDFS: Invasive 
Table 4: Ongoing clinical trials of anti-HER2 therapeutic antibodies

\begin{tabular}{|c|c|c|c|c|c|}
\hline Antibody & Trial & Phase & Patient Population & Treatment & Primary Completion \\
\hline \multirow[t]{4}{*}{ Trastuzumab } & $\begin{array}{l}\text { NCT02614794 } \\
\text { (HER2CLIMB) }^{73}\end{array}$ & II & $\begin{array}{l}\text { Locally advanced or HER2-positive } \\
\text { MBC }(n=480)\end{array}$ & $\begin{array}{l}\text { Tucatinib / Placebo + } \\
\text { capecitabine + trastuzumab }\end{array}$ & July 2021 \\
\hline & $\begin{array}{l}\text { NCT02625441 } \\
(\text { BOLD-1) }\end{array}$ & III & $\begin{array}{l}\text { Early HER2-positive breast cancer } \\
(n=1,366)\end{array}$ & $\begin{array}{l}\text { Trastuzumab + pertuzumab + } \\
\text { docetaxel }\end{array}$ & June 2023 \\
\hline & NCT0181039375 & III & HER2-positive MBC $(n=114)$ & $\begin{array}{l}\text { Trastuzumab / participant } \\
\text { preference for subcutaneous }\end{array}$ & August 2019 \\
\hline & NCT0178542076 & III & $\begin{array}{l}\text { HER2-neu positive operable breast } \\
\text { cancer }(n=1,100)\end{array}$ & Trastuzumab + placebo & February 2021 \\
\hline \multirow[t]{2}{*}{ Pertuzumab } & $\begin{array}{l}\text { NCT02536339 } \\
\text { (PATRICIA) }^{77}\end{array}$ & II & $\begin{array}{l}\text { HER2-positive } M B C \text { with central } \\
\text { nervous system progression post- } \\
\text { radiotherapy }(n=40)\end{array}$ & $\begin{array}{l}\text { Pertuzumab + high-dose } \\
\text { trastuzumab }\end{array}$ & March 2020 \\
\hline & $\begin{array}{l}\text { NCT02514681 } \\
\text { (PRECIOUS) }^{78}\end{array}$ & III & $\begin{array}{l}\text { HER2-positive advanced breast } \\
\text { cancer }(n=370)\end{array}$ & $\begin{array}{l}\text { Pertuzumab + trastuzumab + } \\
\text { chemotherapy }\end{array}$ & July 2019 \\
\hline \multirow{3}{*}{$\begin{array}{l}\text { Transtuzumab } \\
\text { emtansine (T- } \\
\text { DM1) }\end{array}$} & NCT0308493967 & III & $\begin{array}{l}\text { HER2-positive locally advanced or } \\
\text { MBC }(n=350)\end{array}$ & T-DM1/ lapatinib + capecitabine & October 2019 \\
\hline & $\begin{array}{l}\text { NCT01772472 } \\
\text { (KATHERINE) }^{79}\end{array}$ & III & $\begin{array}{l}\text { HER2-positive breast cancer } \\
(n=1,487)\end{array}$ & T-DM1/ Trastuzumab & April 2023 \\
\hline & NCT0196647168 & III & $\begin{array}{l}\text { Operable HER2-positive } \\
\text { primary breast cancer }(n=1,846)\end{array}$ & $\begin{array}{l}\text { T-DM1 + pertuzumab + } \\
\text { anthracyclines / trastuzumab + } \\
\text { pertuzumab + a taxane }\end{array}$ & January 2024 \\
\hline
\end{tabular}

HER2: Human epidermal growth factor receptor 2, MBC: Metastatic breast cancer, T-DM1: Trastuzumab emtansine 
For T-DM1, none of the phase II/III clinical trials have assessed on treatment-naïve HER2-positive breast cancer patients in combination with chemotherapy. Nonetheless, T-DM1 in combination with pertuzumab and docetaxel might represent the ideal chemotherapycontaining regimen where the ORR achieved was high $(80 \%)^{63}$ compared with another chemotherapy-containing regimen (T-DM1 plus pertuzumab and paclitaxel; ORR: $50 \%)^{62}$. In terms of T-DM1 in combination with chemotherapy-free regimen, the phase III KRISTINE study has demonstrated that T-DM1 plus pertuzumab showed lower PCR than chemotherapy-containing regimen ${ }^{66}$.

\section{CONCLUSION}

Ongoing phase III clinical trials are assessing the combination of T-DM1 with capecitabine in HER2positive locally advanced or MBC $(n=350$; NCT03084939) ${ }^{67}$, or T-DM1 plus pertuzumab in combination with anthracyclines in operable HER2-positive breast cancer patients $(n=1,86$; NCT01966471) ${ }^{68}$. Taken together, these indicate that improved outcome is attributable to treatment selection in combination with antiHER2 antibodies instead of replacing chemotherapy altogether with current line of anti-HER2 therapeutic antibodies. Finally, large clinical trials of anti-HER2 antibodies in early HER2-positive or operable breast cancer are currently underway.

\section{Acknowledgements}

The preparation of this article was supported by the Bridging Grant, Universiti Sains Malaysia (304.PPSP.6316332) awarded to K.K.W and USM Fellowship Scheme awarded to S.M.N.H.

\section{Conflict of interest statement}

All authors declare that there are no conflicts of interest.

\section{Authors' contributions}

K.K.W. and S.M.N.H. conceived and designed the manuscript, conducted literature searches, made the figures, prepared the tables, and wrote the manuscript. A.D.P., F.A.H. and M.M.Y. edited and revised the manuscript. All authors read and approved the final manuscript.

\section{Conflict of interest}

The authors declare no potential conflict of interest.

\section{REFERENCES}

1. Torre LA, Siegel RL, Ward EM, et al. Global Cancer Incidence and Mortality Rates and Trends--An Update. Cancer Epidemiol Biomarkers Prev 2016; 25: 16-27. DOI: 10.1158/1055-9965.EPI-15-0578.

2. Global Burden of Disease Cancer C, Fitzmaurice C, Dicker D, et al. The Global
Burden of Cancer 2013. JAMA Oncol 2015; 1: 505-527. DOI: 10.1001/jamaoncol.2015.0735.

3. Siegel RL, Miller KD and Jemal A. Cancer statistics, 2018. CA Cancer J Clin 2018; 68: 7-30. DOI: 10.3322/caac.21442.

4. Cheang MC, Voduc D, Bajdik C, et al. Basallike breast cancer defined by five biomarkers has superior prognostic value than triple-negative phenotype. Clin Cancer Res 2008; 14: 1368-1376. DOI: 10.1158/1078-0432.CCR-07-1658.

5. Blows FM, Driver KE, Schmidt MK, et al. Subtyping of Breast Cancer by Immunohistochemistry to Investigate a Relationship between Subtype and Short and Long Term Survival: A Collaborative Analysis of Data for 10,159 Cases from 12 Studies. PLoS Med 2010; 7. DOI: https://doi.org/10.1371/journal.pmed.100 $\underline{0279}$.

6. Rakha EA, Pinder SE, Bartlett JM, et al. Updated UK Recommendations for HER2 assessment in breast cancer. Journal of clinical pathology 2015; 68: 93-99. DOI: 10.1136/jclinpath-2014-202571.

7. Press MF, and C-CC and DJ S Expression of the HER-2/neu protooncogenein normal human adult and fetal tissues. Oncogene 1990; 5: 953-962.

8. Tse C, Gauchez A, Jacot Wa, et al. HER2 shedding and serum HER2 extracellular domain: Biology and clinical utility in breast cancer. cancer Treat Rev 2011; 38: 133142.

9. Slamon DJ, Godolphin W, Jones LA, et al. Studies of the HER-2/neu proto-oncogene in human breast and ovarian cancer. Science 1989; 244: 707-712.

10. Owens MA, Horten BC and Da Silva MM. HER2 amplification ratios by fluorescence in situ hybridization and correlation with immunohistochemistry in a cohort of 6556 breast cancer tissues. Clin Breast Cancer 2004; 5: 63-69.

11. Vu T and Claret FX. Trastuzumab: updated mechanisms of action and resistance in breast cancer. Front Oncol 2012; 2: 62. DOI: 10.3389/fonc.2012.00062.

12. Hudis CA. Trastuzumab--mechanism of action and use in clinical practice. $\mathrm{N}$ Engl J Med 2007; 357: 39-51. DOI: 10.1056/NEJMra043186. 
13. Boekhout AH, Beijnen JH and Schellens JH. Trastuzumab. Oncologist 2011; 16: 800810. DOI: $10.1634 /$ theoncologist.20100035.

14. Tai $\mathrm{W}$, Mahato $\mathrm{R}$ and Cheng $\mathrm{K}$. The role of HER2 in cancer therapy and targeted drug delivery. J Control Release 2010; 146: 264275. DOI: 10.1016/j.jconrel.2010.04.009.

15. Shak S. Overview of the trastuzumab (Herceptin) anti-HER2 monoclonal antibody clinical program in HER2-overexpressing metastatic breast cancer. Herceptin Multinational Investigator Study Group. Semin Oncol 1999; 26: 71-77.

16. Baselga J, Tripathy D, Mendelsohn J, et al. Phase II study of weekly intravenous recombinant humanized anti-p185HER2 monoclonal antibody in patients with HER2/neu-overexpressing metastatic breast cancer. J Clin Oncol 1996; 14: 737744. DOI: $10.1200 / J C 0.1996 .14 .3 .737$.

17. Cobleigh MA, Vogel CL, Tripathy $D$, et al. Multinational study of the efficacy and safety of humanized anti-HER2 monoclonal antibody in women who have HER2overexpressing metastatic breast cancer that has progressed after chemotherapy for metastatic disease. J Clin Oncol 1999; 17: 2639-2648.

10.1200/JCO.1999.17.9.2639.

18. Vogel $C L$, Cobleigh MA, Tripathy $D$, et al. Efficacy and safety of trastuzumab as a single agent in first-line treatment of HER2overexpressing metastatic breast cancer. J Clin Oncol 2002; 20: 719-726. DOI: 10.1200/JCO.2002.20.3.719.

19. Baselga J, Carbonell X, Castaneda-Soto NJ, et al. Phase II study of efficacy, safety, and pharmacokinetics of trastuzumab monotherapy administered on a 3-weekly schedule. J Clin Oncol 2005; 23: 2162-2171. DOI: $10.1200 /$ JCO.2005.01.014.

20. Cameron D, Piccart-Gebhart MJ, Gelber RD, et al. 11 years' follow-up of trastuzumab after adjuvant chemotherapy in HER2positive early breast cancer: final analysis of the HERceptin Adjuvant (HERA) trial. Lancet 2017; 389: 1195-1205. DOI: $10.1016 / \mathrm{S} 0140-6736(16) 32616-2$.

21. Tolaney SM, Barry WT, Dang CT, et al. Adjuvant paclitaxel and trastuzumab for node-negative, HER2-positive breast cancer. N Engl J Med 2015; 372: 134-141. DOI: $10.1056 /$ NEJMoa1406281.

22. Awada A, Colomer R, Inoue $\mathrm{K}$, et al. Neratinib Plus Paclitaxel vs Trastuzumab
Plus Paclitaxel in Previously Untreated Metastatic ERBB2-Positive Breast Cancer: The NEfERT-T Randomized Clinical Trial. JAMA Oncol 2016; 2: 1557-1564. DOI: 10.1001/jamaoncol.2016.0237.

23. Robert N, Leyland-Jones B, Asmar L, et al. Randomized phase III study of trastuzumab, paclitaxel, and carboplatin compared with trastuzumab and paclitaxel in women with HER-2-overexpressing metastatic breast cancer. J Clin Oncol 2006; 24: 27862792.DOI: 10.1200/JCO.2005.04.1764.

24. Carey LA, Berry DA, Cirrincione CT, et al. Molecular Heterogeneity and Response to Neoadjuvant Human Epidermal Growth Factor Receptor 2 Targeting in CALGB 40601, a Randomized Phase III Trial of Paclitaxel Plus Trastuzumab With or Without Lapatinib. J Clin Oncol 2016; 34: 542-549. DOI: 10.1200/JCO.2015.62.1268.

25. Harbeck N, Huang CS, Hurvitz S, et al. Afatinib plus vinorelbine versus trastuzumab plus vinorelbine in patients with HER2-overexpressing metastatic breast cancer who had progressed on one previous trastuzumab treatment (LUXBreast 1): an open-label, randomised, phase 3 trial. Lancet Oncol 2016; 17: 357366. DOI:10.1016/S14702045(15)00540-9.

26. Murthy R, Borges VF, Conlin A, et al. Tucatinib with capecitabine and trastuzumab in advanced HER2-positive metastatic breast cancer with and without brain metastases: a non-randomised, openlabel, phase 1b study. Lancet Oncol 2018; 19:

$880-888$. DOI:10.1016/S14702045(18)30256-0.

27. Pistilli B, Pluard T, Urruticoechea A, et al. Phase II study of buparlisib (BKM120) and trastuzumab in patients with HER2+ locally advanced or metastatic breast cancer resistant to trastuzumab-based therapy. Breast cancer research and treatment 2018; 168: 357-364. DOI: 10.1007/s10549-0174596-7.

28. Baselga J, Bradbury I, Eidtmann H, et al. Lapatinib with trastuzumab for HER2positive early breast cancer (NeoALTTO): a randomised, open-label, multicentre, phase 3 trial. Lancet 2012; 379: 633-640. DOI: 10.1016/S0140-6736(11)61847-3.

29. 2Johnston SRD, Hegg R, Im SA, et al. Phase III, Randomized Study of Dual Human Epidermal Growth Factor Receptor 2 (HER2) Blockade With Lapatinib Plus Trastuzumab in Combination With an Aromatase Inhibitor in Postmenopausal Women With HER2Positive, Hormone Receptor-Positive 
Metastatic Breast Cancer: ALTERNATIVE. J Clin Oncol 2018; 36: 741-748. DOI: $10.1200 / J C 0.2017 .74 .7824$.

30. Loi S, Giobbie-Hurder A, Gombos A, et al. Pembrolizumab plus trastuzumab in trastuzumab-resistant, advanced, HER2positive breast cancer (PANACEA): a singlearm, multicentre, phase $1 \mathrm{~b}-2$ trial. The Lancet Oncology 2019; 20: 371-382. DOI: $10.1016 / \mathrm{S} 1470-2045(18) 30812-\mathrm{X}$.

31. Bighin C, Pronzato $\mathrm{P}$ and Del Mastro L. Trastuzumab emtansine in the treatment of HER-2-positive metastatic breast cancer patients. Future Oncol 2013; 9: 955-957. DOI: $10.2217 /$ fon. 13.74 .

32. McCormack PL. Pertuzumab: a review of its use for first-line combination treatment of HER2-positive metastatic breast cancer. Drugs 2013; 73: 1491-1502. DOI: 10.1007/s40265-013-0109-0.

33. Pedersen MW, Jacobsen HJ, Koefoed K, et al. Targeting Three Distinct HER2 Domains with a Recombinant Antibody Mixture Overcomes Trastuzumab Resistance. Mol Cancer Ther 2015; 14: 669-680. DOI: 10.1158/1535-7163.MCT-14-0697.

34. Chung $C$ and Lam MS. Pertuzumab for the treatment of human epidermal growth factor receptor type 2-positive metastatic breast cancer. Am J Health Syst Pharm 2013; 70: 1579-1587. DOI: 10.2146/ajhp120735.

35. Cortes J, Fumoleau P, Bianchi GV, et al. Pertuzumab monotherapy after trastuzumab-based treatment and subsequent reintroduction of trastuzumab: activity and tolerability in patients with advanced human epidermal growth factor receptor 2-positive breast cancer. J Clin Oncol 2012; 30: 1594-1600. DOI: 10.1200/JCO.2011.37.4207.

36. Gianni L, Pienkowski T, Im YH, et al. Efficacy and safety of neoadjuvant pertuzumab and trastuzumab in women with locally advanced, inflammatory, or early HER2-positive breast cancer (NeoSphere): a randomised multicentre, open-label, phase 2 trial. Lancet Oncol 2012; 13: 25-32. DOI: 10.1016/S14702045(11)70336-9.

37. Schneeweiss A, Chia S, Hickish $T$, et al. Pertuzumab plus trastuzumab in combination with standard neoadjuvant anthracycline-containing and anthracycline-free chemotherapy regimens in patients with HER2-positive early breast cancer: a randomized phase II cardiac safety study (TRYPHAENA). Ann Oncol 2013; 24: 2278-2284. DOI: 10.1093/annonc/mdt182.

38. Smyth LM, lyengar NM, Chen MF, et al. Weekly paclitaxel with trastuzumab and pertuzumab in patients with HER2overexpressing metastatic breast cancer: overall survival and updated progressionfree survival results from a phase II study. Breast Cancer Res Treat 2016; 158: 91-97. DOI: 10.1007/s10549-016-3851-7.

39. Perez EA, Lopez-Vega JM, Petit T, et al. Safety and efficacy of vinorelbine in combination with pertuzumab and trastuzumab for first-line treatment of patients with HER2-positive locally advanced or metastatic breast cancer: VELVET Cohort 1 final results. Breast Cancer Res 2016; 18: 126. DOI: 10.1186/s13058-016-0773-6.

40. Araki K, Fukada I, Yanagi $\mathrm{H}$, et al. First report of eribulin in combination with pertuzumab and trastuzumab for advanced HER2-positive breast cancer. Breast 2017; 35: 78-84. DOI: 10.1016/j.breast.2017.06.015.

41. Wildiers $H$, Tryfonidis $K$, Dal Lago L, et al. Pertuzumab and trastuzumab with or without metronomic chemotherapy for older patients with HER2-positive metastatic breast cancer (EORTC 7511110114): an open-label, randomised, phase 2 trial from the Elderly Task Force/Breast Cancer Group. The Lancet Oncology 2018; 19: 323-336. DOI: 10.1016/S14702045(18)30083-4.

42. Swain SM, Baselga J, Kim SB, et al. Pertuzumab, trastuzumab, and docetaxel in HER2-positive metastatic breast cancer. N Engl J Med 2015; 372: 724-734. DOI: 10.1056/NEJMoa1413513.

43. Urruticoechea A, Rizwanullah M, Im SA, et al. Randomized Phase III Trial of Trastuzumab Plus Capecitabine With or Without Pertuzumab in Patients With Human Epidermal Growth Factor Receptor 2-Positive Metastatic Breast Cancer Who Experienced Disease Progression During or After Trastuzumab-Based Therapy. J Clin Oncol 2017; 35: 3030-3038. DOI: $10.1200 / J C O .2016 .70 .6267$.

44. Urruticoechea A, Rizwanullah M, Im S-A, et al. Final overall survival (OS) analysis of PHEREXA: A randomized phase III trial of trastuzumab $(\mathrm{H})$ + capecitabine $(\mathrm{X}) \pm$ pertuzumab $(P)$ in patients with HER2positive metastatic breast cancer (MBC) who experienced disease progression during 
or after H-based therapy. Journal of Clinical Oncology 2018; 36: 1013-1013. DOI: 10.1200/JCO.2018.36.15_suppl.1013.

45. von Minckwitz G, Procter M, de Azambuja $\mathrm{E}$, et al. Adjuvant Pertuzumab and Trastuzumab in Early HER2-Positive Breast Cancer. The New England journal of medicine 2017; 377: 122-131. DOI: 10.1056/NEJMoa1703643.

46. Beitsch $\mathrm{P}$, Whitworth $\mathrm{P}$, Baron $\mathrm{P}$, et al. Pertuzumab/Trastuzumab/CT Versus Trastuzumab/CT Therapy for HER2+ Breast Cancer: Results from the Prospective Neoadjuvant Breast Registry Symphony Trial (NBRST). Ann Surg Oncol 2017; 24: 2539-2546. DOI: 10.1245/s10434-017-5863$\mathrm{x}$.

47. Baselga J, Gelmon KA, Verma S, et al. Phase Il trial of pertuzumab and trastuzumab in patients with human epidermal growth factor receptor 2-positive metastatic breast cancer that progressed during prior trastuzumab therapy. J Clin Oncol 2010; 28: 1138-1144.

DOI:

$10.1200 / J C 0.2009 .24 .2024$.

48. Beaver JA, Amiri-Kordestani L, Charlab R, et al. FDA Approval: Palbociclib for the Treatment of Postmenopausal Patients with Estrogen Receptor-Positive, HER2-Negative Metastatic Breast Cancer. Clin Cancer Res 2015; 21: 4760-4766. DOI: 10.1158/10780432.CCR-15-1185.

49. Nur Husna SM, Tan HT, Mohamud R, et al. Inhibitors targeting CDK4/6, PARP and PI3K in breast cancer: a review. Ther Adv Med Oncol 2018; 10: 1758835918808509. DOI: $10.1177 / 1758835918808509$.

50. Gianni L, Bisagni G, Colleoni $M$, et al. Neoadjuvant treatment with trastuzumab and pertuzumab plus palbociclib and fulvestrant in HER2-positive, ER-positive breast cancer (NA-PHER2): an exploratory, open-label, phase 2 study. Lancet Oncol 2018; 19: 249-256. DOI: 10.1016/S14702045(18)30001-9.

51. Li C, Wang B, Chen SC, et al. Exposureresponse analyses of trastuzumab emtansine in patients with HER2-positive advanced breast cancer previously treated with trastuzumab and a taxane. Cancer Chemother Pharmacol 2017; 80: 1079-1090. DOI: $10.1007 / \mathrm{s} 00280-017-3440-4$.

52. Lewis Phillips GD, Li G, Dugger DL, et al. Targeting HER2-positive breast cancer with trastuzumab-DM1, an antibody-cytotoxic drug conjugate. Cancer Res 2008; 68: 9280-
9290. DOI: 10.1158/0008-5472.CAN-081776.

53. Hong $E$ a and $R$ C. Linker Design for Antibody-Drug Conjugates. Springer, Cham, 2015.

54. Krop IE, Kim SB, Martin AG, et al. Trastuzumab emtansine versus treatment of physician's choice in patients with previously treated HER2-positive metastatic breast cancer (TH3RESA): final overall survival results from a randomised open-label phase 3 trial. The Lancet Oncology 2017; 18: 743-754. DOI: 10.1016/S1470-2045(17)30313-3.

55. Barok $M$, Joensuu $H$ and Isola J. Trastuzumab emtansine: mechanisms of action and drug resistance. Breast cancer research : BCR 2014; 16: 209. DOI: 10.1186/bcr3621.

56. Junttila TT, Li G, Parsons $K$, et al. Trastuzumab-DM1 (T-DM1) retains all the mechanisms of action of trastuzumab and efficiently inhibits growth of lapatinib insensitive breast cancer. Breast Cancer Res Treat 2011; 128: 347-356. DOI: $10.1007 / \mathrm{s} 10549-010-1090-x$.

57. Krop IE, Beeram M, Modi S, et al. Phase I study of trastuzumab-DM1, an HER2 antibody-drug conjugate, given every 3 weeks to patients with HER2-positive metastatic breast cancer. J Clin Oncol 2010; 28: 2698-2704. DOI: 10.1200/JCO.2009.26.2071.

58. Beeram M, Krop IE, Burris HA, et al. A phase 1 study of weekly dosing of trastuzumab emtansine (T-DM1) in patients with advanced human epidermal growth factor 2-positive breast cancer. Cancer 2012; 118: 5733-5740. DOI: 10.1002/cncr.27622.

59. Yamamoto $\mathrm{H}$, Ando $\mathrm{M}$, Aogi K, et al. Phase I and pharmacokinetic study of trastuzumab emtansine in Japanese patients with HER2positive metastatic breast cancer. Jpn J Clin Oncol 2015; 45: 12-18. DOI: 10.1093/jjco/hyu160.

60. Burris HA, 3rd, Rugo HS, Vukelja SJ, et al. Phase II study of the antibody drug conjugate trastuzumab-DM1 for the treatment of human epidermal growth factor receptor 2 (HER2)-positive breast cancer after prior HER2-directed therapy. J Clin Oncol 2011; 29: 398-405. DOI: 10.1200/JCO.2010.29.5865.

61. Verma S, Miles D, Gianni L, et al. Trastuzumab emtansine for HER2-positive advanced breast cancer. N Engl J Med 2012; 
367: 1783-1791. DOI: 10.1056/NEJMoa1209124.

62. Krop IE, Modi S, LoRusso PM, et al. Phase $1 \mathrm{~b} / 2 \mathrm{a}$ study of trastuzumab emtansine ( $\mathrm{T}$ DM1), paclitaxel, and pertuzumab in HER2positive metastatic breast cancer. Breast Cancer Res 2016; 18: 34. DOI: 10.1186/s13058-016-0691-7.

63. Martin M, Fumoleau P, Dewar JA, et al. Trastuzumab emtansine (T-DM1) plus docetaxel with or without pertuzumab in patients with HER2-positive locally advanced or metastatic breast cancer: results from a phase $\mathrm{lb} / \mathrm{ll}$ a study. Annals of oncology : official journal of the European Society for Medical Oncology / ESMO 2016; 27: 1249-1256. DOI: 10.1093/annonc/mdw157.

64. Miller KD, Dieras V, Harbeck N, et al. Phase Ila trial of trastuzumab emtansine with pertuzumab for patients with human epidermal growth factor receptor 2positive, locally advanced, or metastatic breast cancer. J Clin Oncol 2014; 32: 1437 1444. DOI: $10.1200 /$ JCO.2013.52.6590.

65. Perez EA, Barrios C, Eiermann W, et al. Trastuzumab Emtansine With or Without Pertuzumab Versus Trastuzumab Plus Taxane for Human Epidermal Growth Factor Receptor 2-Positive, Advanced Breast Cancer: Primary Results From the Phase III MARIANNE Study. J Clin Oncol 2017; 35: 141-148. DOI: 10.1200/JCO.2016.67.4887.

66. Hurvitz SA, Martin M, Symmans WF, et al. Neoadjuvant trastuzumab, pertuzumab, and chemotherapy versus trastuzumab emtansine plus pertuzumab in patients with HER2-positive breast cancer (KRISTINE): a randomised, open-label, multicentre, phase 3 trial. Lancet Oncol 2018; 19: 115126. DOI: $10.1016 /$ S1470-2045(17)30716-7.

67. Efficacy and Safety of Trastuzumab Emtansine in Chinese Participants With Human Epidermal Growth Factor Receptor 2 (HER2)-Positive Locally Advanced or Metastatic Breast Cancer, https://clinicaltrials.gov/ct2/show/NCT03 084939 (2018, accessed 27 April 2019).

68. A Study of Trastuzumab Emtansine (Kadcyla) Plus Pertuzumab (Perjeta) Following Anthracyclines in Comparison With Trastuzumab (Herceptin) Plus Pertuzumab and a Taxane Following Anthracyclines as Adjuvant Therapy in Participants With Operable HER2-Positive Primary Breast Cancer, https://clinicaltrials.gov/ct2/show/NCT01 966471 (2019, accessed 27 April 2019 2019).
69. Hurvitz SA, Dirix L, Kocsis J, et al. Phase II randomized study of trastuzumab emtansine versus trastuzumab plus docetaxel in patients with human epidermal growth factor receptor 2positive metastatic breast cancer. Journal of clinical oncology : official journal of the American Society of Clinical Oncology 2013; 31: 1157-1163. DOI: 10.1200/JCO.2012.44.9694.

70. Krop IE, LoRusso P, Miller KD, et al. A phase II study of trastuzumab emtansine in patients with human epidermal growth factor receptor 2-positive metastatic breast cancer who were previously treated with trastuzumab, lapatinib, an anthracycline, a taxane, and capecitabine. $\mathrm{J}$ Clin Oncol 2012; 30: 3234-3241. DOI: 10.1200/JCO.2011.40.5902.

71. Kashiwaba $M$, Ito $Y$, Takao $S$, et al. A multicenter Phase II study evaluating the efficacy, safety and pharmacokinetics of trastuzumab emtansine in Japanese patients with heavily pretreated HER2positive locally recurrent or metastatic breast cancer. Jpn J Clin Oncol 2016; 46: 407-414. DOI: 10.1093/jjco/hyw013.

72. Harbeck N, Gluz O, Christgen M, et al. DeEscalation Strategies in Human Epidermal Growth Factor Receptor 2 (HER2)-Positive Early Breast Cancer (BC): Final Analysis of the West German Study Group Adjuvant Dynamic Marker-Adjusted Personalized Therapy Trial Optimizing Risk Assessment and Therapy Response Prediction in Early BC HER2- and Hormone Receptor-Positive Phase II Randomized Trial-Efficacy, Safety, and Predictive Markers for 12 Weeks of Neoadjuvant Trastuzumab Emtansine With or Without Endocrine Therapy (ET) Versus Trastuzumab Plus ET. Journal of clinical oncology : official journal of the American Society of Clinical Oncology 2017; 35: 3046 3054. DOI: 10.1200/JCO.2016.71.9815.

73. Phase 2 Study of Tucatinib vs Placebo in Combination With Capecitabine \& Trastuzumab in Patients With Advanced HER2+ Breast Cancer (HER2CLIMB), https://clinicaltrials.gov/ct2/results?cond =\&term=NCT02614794 (2018, accessed August 15 2018).

74. Adjuvant Trastuzumab, Pertuzumab Plus Docetaxel in the Treatment of Early HER2positive Breast Cancer (BOLD-1), https://clinicaltrials.gov/ct2/show/NCT02 625441?term=NCT02625441\&rank=1 (2018, accessed Mei 14 2018). 
75. A Study to Assess Preference for Subcutaneous Trastuzumab Treatment in Participants With Human Epidermal Growth Factor Receptor (HER)2-Positive Metastatic Breast Cancer Responding to First-Line Intravenous Trastuzumab for at Least 3 Years,

https: / clinicaltrials.gov/ct2/show/NCT01 810393 (2018, accessed 14 May 2018).

76. Pre-Operative Trastuzumab in Operable Breast Cancer, https: / / clinicaltrials.gov/ct2/show/NCT01 785420 (2018, accessed 14 May 2018).

77. Pertuzumab With High-Dose Trastuzumab in Human Epidermal Growth Factor Receptor 2 (HER2)-Positive Metastatic Breast Cancer (MBC) With Central Nervous System (CNS) Progression Post-Radiotherapy, https: / /clinicaltrials.gov/ct2/show/NCT02 536339 (2018, accessed 14 May 2018).

78. A Phase III Trial of Pertuzumab Retreatment in Previously Pertuzumab Treated Her2Positive Advanced Breast Cancer (PRECIOUS),

https: / /clinicaltrials.gov/ct2/show/NCT02 514681 (2018, accessed 14 May 2018).

79. A Study of Trastuzumab Emtansine Versus Trastuzumab as Adjuvant Therapy in Patients With HER2-Positive Breast Cancer Who Have Residual Tumor in the Breast or Axillary Lymph Nodes Following Preoperative Therapy (KATHERINE), https: / /clinicaltrials.gov/ct2/show/NCT01 772472 (2018, accessed 14 May 2018). 